\title{
Renal toxicity of targeted therapies for renal cell carcinoma in patients with normal and impaired kidney function
}

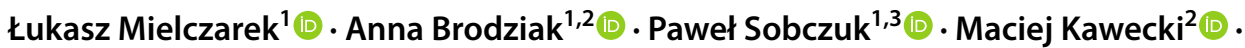

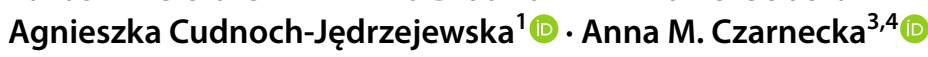

Received: 13 December 2020 / Accepted: 13 March 2021 / Published online: 25 March 2021

(c) The Author(s) 2021

\begin{abstract}
The introduction of novel targeted therapies during the last 2 decades has led to a significant improvement in patients' clinical outcomes with renal cell carcinoma. However, this improvement came at the price of a whole new spectrum of adverse events, including renal toxicity. Systemic treatment of patients with kidney neoplasms who often present with impairment of kidney function, even prior to treatment, poses an increasing diagnostic and therapeutic challenge for clinicians. Common lifestyle-related comorbidities, i.e., hypertension and diabetes, may contribute to further impairment of kidney function. The lack of official guidelines and the exclusion of patients with reduced kidney function from the clinical trials of recently approved drugs complicate the issue even further. Early detection and correct management of renal toxic effects are crucial to preserve kidney function and ensure the optimal administration of life-prolonging therapies. This review presents detailed information on the renal toxicities of three groups of drugs commonly used in renal cell carcinoma treatment: tyrosine kinase inhibitors, mammalian target of rapamycin inhibitors, and immune checkpoint inhibitors. We outline the incidence and underlying mechanisms of renal adverse effects with a focus on patients on renal replacement therapy, as well as present suggestions for their management.
\end{abstract}

Keywords Renal cell cancer $\cdot$ TKI $\cdot$ MTORi $\cdot$ Immune checkpoint inhibitors $\cdot$ Renal insufficiency $\cdot$ Nephrotoxicity

\section{Introduction}

Renal cell carcinoma (RCC) is the 6th most common cancer type in men and the tenth most common in women, accounting for $5 \%$ and $3 \%$ of all cancer diagnoses, respectively. It remains one of the most lethal urological malignancies [1].

Anna M. Czarnecka

anna.czarnecka@gmail.com

1 Department of Experimental and Clinical Physiology, Laboratory of Centre for Preclinical Research, Medical University of Warsaw, Warsaw, Poland

2 Department of Oncology and Radiotherapy, Maria Sklodowska-Curie National Research Institute of Oncology, Warsaw, Poland

3 Department of Soft Tissue/Bone Sarcoma and Melanoma, Maria Sklodowska-Curie National Research Institute of Oncology, Warsaw, Poland

4 Department of Experimental Pharmacology, Mossakowski Medical Research Centre Polish Academy of Sciences, Warsaw, Poland
With growing incidence rates, mostly in high-income countries, RCC arises as an important diagnostic and therapeutic challenge. Common lifestyle-related diseases, i.e., hypertension and diabetes, are independent risk factors of RCC development, and, therefore, it is not surprising that hypertensive nephrosclerosis and diabetic nephropathy are common in RCC patients [2-4]. A history of kidney disease is an independent risk factor of RCC (HR 2.58, 95\% CI 1.21-5.50) [2]. Approximately $26 \%$ of RCC patients have chronic kidney disease (CKD) even before RCC treatment [5]. Patients with end-stage renal disease (ESRD) requiring long-term dialysis or after renal transplantation are at a higher risk of developing RCC $-0.3 \%$ and $0.7 \%$, respectively $[6,7]$, compared to approximately $0.005 \%$ in the general population [8]. However, despite RCC's higher incidence in ESRD patients, tumors in this population exhibit favorable clinical and pathological features $[9,10]$. RCCs in native kidneys of ESRD patients are usually asymptomatic, small, low stage, low grade, and non-metastatic at diagnosis [9]. These differences may be attributed to increased surveillance and the distinct pathophysiology of these tumors, including unique 
histopathological subtypes such as acquired cystic diseaseassociated RCC and clear cell papillary RCC [11].

Despite improvements in renal tumors surgery, even patients without previously diagnosed CKD may develop renal insufficiency after RCC resection. New-onset CKD secondary to surgery develops more often in patients undergoing radical nephrectomy than partial nephrectomy, with various rates reported by studies $(55.7-70 \%$ vs. $6.2-17.4 \%$, respectively) [5, 12]. RCC's surgical treatment may also result in acute kidney injury (AKI) in up to $5 \%$ of cases [13]. Patients presenting with sporadic bilateral and/or multifocal renal tumors represent a unique population, accounting for up to 5\% of all RCC patients [14]. Despite the introduction of nephron-sparing surgery, a substantial group of patients in this population needs to be treated with bilateral nephrectomy and subsequently develops renal insufficiency that must be treated with dialyzes. Surgical resection is a curative procedure in most localized RCC cases, but 20-40\% of the patients will ultimately develop distant metastases and require systemic treatment in the first 5 years after primary tumor surgery [15]. The last few decades brought tremendous changes to the therapeutic landscape of metastatic RCC, with the development of numerous tyrosine kinase inhibitors (TKIs), mammalian target of rapamycin inhibitors (mTORis), and immune checkpoint inhibitors (ICPIs). This progress has significantly improved RCC patients' clinical outcomes, at the price of a whole new spectrum of adverse events (AEs), including renal toxicities. Because of the many links between cancer, kidneys, and drug metabolism, nephrologists should become aware of new anticancer drugs' potential nephrotoxicity and be actively involved in certain aspects of cancer care. Emergence of a new subspecialty, onconephrology, underlines the need for a close collaboration between oncologists and nephrologists [16]. In this paper, we comprehensively review renal toxicities associated with the aforementioned classes of drugs used in the treatment of RCC from an epidemiological, pathophysiological, and clinical point of view. Additionally, we summarize recommendations and underline differences in systemic treatment between patients with CKD and ESRD undergoing hemodialysis.

\section{Renal toxicities of tyrosine kinase inhibitors}

\section{Incidence}

TKIs are one of the most commonly used groups of drugs in RCC treatment and include sunitinib, pazopanib, sorafenib, axitinib, and cabozantinib. All abovementioned drugs are multitargeted TKIs, which means that they interfere with the activity of more than one family of receptor tyrosine kinases, including vascular endothelial growth factor receptor (VEGFR), platelet-derived growth factor receptor (PDGFR), fibroblast growth factor receptor (FGFR), and epidermal growth factor receptor (EGFR), and all share a similar structure. Additionally, sorafenib is a potent inhibitor of serine/threonine-protein RAF kinases. Their shared mechanism of action contributes to their similar side effects. The most common AEs involve gastrointestinal, skin, bone marrow, and cardiovascular system toxicities. Renal toxicities are also frequently reported; however, data regarding their exact rate are inconsistent (Table 1).

Most TKI-related renal AEs include mild renal injury, defined as a clinically insignificant serum creatinine elevation that develops in up to $70 \%$ of patients receiving sunitinib [17-20]. Clinically important renal insufficiency may develop in $7.7 \%$ to $33 \%$ of patients treated with sunitinib $[21,22]$. In the AXIS trial, deterioration of kidney function (defined as creatinine clearance elevation) was observed in $41 \%$ of patients treated with axitinib and in $55 \%$ of patients treated with sorafenib during the first-line treatment; however, a clinically significant increase of creatinine clearance (grades 3 and 4 according to CTCAE version 3.0) was extremely rare in case of sorafenib $(<1 \%)$ and absent in patients receiving axitinib [23]. Pazopanib treatment is associated with a similar prevalence of kidney function deterioration, as observed in the COMPARTZ trial, where increased creatinine levels were present in $32 \%$ of patients [24]. Nevertheless, clinically significant kidney function impairment was extremely rare, with $<1 \%$ of acute kidney failure cases in this trial. In cabozantinib trials, i.e., CABOSUN and METEOR, $5 \%$ and $25 \%$ of patients demonstrated elevated creatinine levels, respectively (Table 1). In a retrospective analysis of Japanese patients treated with sunitinib, sorafenib, or axitinib in first, second, or third line, deterioration of kidney function was documented, however, with no significant differences between creatinine clearance at baseline and that at the end of therapy between patients receiving different lines of treatment [25].

Another side effect related to renal function, proteinuria, may develop in up to $63 \%$ of patients undergoing anti-VEGF therapy, depending on the type of drug (Table 1). According to a recent meta-analysis of newly approved VEGFR-TKIs (regorafenib, vandetanib, cabozantinib, lenvatinib, axitinib), the risk of developing high-grade proteinuria event was significant for patients with RCC [26]. In the course of nephrotic syndrome, heavy proteinuria may be seen in up to $6.5 \%$ of patients treated with anti-VEGF therapies [27].

\section{Mechanisms of nephrotoxicity}

Renal damage induced by TKIs can present with hypertension and proteinuria. In patients receiving anti-VEGF therapy, thrombotic microangiopathy (TMA) is the most common histopathological finding [28]. Cases of 
Table 1 Renal toxicities in major TKI trials

\begin{tabular}{|c|c|c|c|c|c|c|}
\hline \multirow[t]{2}{*}{ Trial } & \multirow[t]{2}{*}{ Drug } & \multirow[t]{2}{*}{ Number of patients } & \multicolumn{4}{|l|}{ Renal related toxicities } \\
\hline & & & Type & $\begin{array}{l}\text { Overall, } \\
\text { any grade } \\
(\%)\end{array}$ & $\begin{array}{l}\text { Grades } \\
3-4 / \mathrm{SAE} \\
(\%)\end{array}$ & Refs. \\
\hline $\begin{array}{l}\text { Renal EFFECT } \\
\text { Phase II, 1st line } \\
\text { NCT00267748 }\end{array}$ & Sunitinib & 147 & Creatinine increase & 69 & 2 & [104] \\
\hline $\begin{array}{l}\text { Phase II, 2nd line } \\
\text { NCT00077974 }\end{array}$ & Sunitinib & 106 & $\begin{array}{l}\text { Creatinine increase } \\
\text { Acute renal failure }^{\mathrm{a}}\end{array}$ & $\begin{array}{l}8.49 \\
2.83\end{array}$ & & [105] \\
\hline $\begin{array}{l}\text { Phase III, 1st line } \\
\text { Registration trial } \\
\text { NCT00083889 }\end{array}$ & Sunitinib & 375 & $\begin{array}{l}\text { Creatinine increase }^{\mathrm{a}} \\
\text { Renal failure }^{\mathrm{a}} \\
\text { Acute renal failure }^{\mathrm{a}} \\
\text { Hematuria }^{\mathrm{a}} \\
\text { Nephrotic syndrome }^{\mathrm{a}}\end{array}$ & $\begin{array}{l}66 \\
1.07 \\
1.07 \\
1.33 \\
0.27\end{array}$ & $\begin{array}{l}\text { ND } \\
1.07 \\
1.07 \\
1.33 \\
0.27\end{array}$ & {$[17,18]$} \\
\hline $\begin{array}{l}\text { COMPARZ (pazopanib vs } \\
\text { sunitinib) } \\
\text { Phase III, 1st line } \\
\text { NCT00720941 }\end{array}$ & Sunitinib & 553 & $\begin{array}{l}\text { Creatinine increase } \\
\text { Proteinuria }^{\mathrm{a}} \\
\text { Acute renal failure }^{\mathrm{a}} \\
\text { Renal failure }^{\mathrm{a}} \\
\text { Hematuria }^{\mathrm{a}}\end{array}$ & $\begin{array}{l}46 \\
14 \\
1.62 \\
0.73 \\
0.18\end{array}$ & $\begin{array}{l}2 \\
0.18 \\
1.64 \\
0.73 \\
0.18\end{array}$ & {$[24]$} \\
\hline $\begin{array}{l}\text { RECORD-3 trial } \\
\text { Phase III } \\
\text { (sunitinib vs everolimus } \\
\text { 1st or 2nd line) } \\
\text { NCT00903175 }\end{array}$ & $\begin{array}{l}\text { Sunitinib 1L, everolimus } \\
\text { 2L/everolimus 1L, suni- } \\
\text { tinib 2L }\end{array}$ & $231 / 238$ & Creatinine increase & $11 / 13$ & $2 / 3$ & {$[106]$} \\
\hline $\begin{array}{l}\text { Phase II } \\
\text { treatment-naive or post- } \\
\text { cytokine } \\
\text { NCT00244764 }\end{array}$ & Pazopanib & 225 & Creatinine increase & 32 & $<1$ & {$[107]$} \\
\hline $\begin{array}{l}\text { Phase II, post-cytokine } \\
\text { NCT00731211 }\end{array}$ & Pazopanib & 55 & $\begin{array}{l}\text { Proteinuria } \\
\text { Renal failure }\end{array}$ & $\begin{array}{l}44 \\
4\end{array}$ & $\begin{array}{l}13 \\
4\end{array}$ & {$[108]$} \\
\hline $\begin{array}{l}\text { Phase III, treatment-naive } \\
\text { or post-cytokine } \\
\text { NCT00334282 }\end{array}$ & Pazopanib & 290 & $\begin{array}{l}\text { Proteinuria } \\
\text { Hematuria }^{\mathrm{a}} \\
\text { Acute kidney injury }^{\mathrm{a}}\end{array}$ & $\begin{array}{l}10 \\
0.24 \\
0\end{array}$ & $\begin{array}{l}2 \\
0.34 \\
0\end{array}$ & {$[109,110]$} \\
\hline $\begin{array}{l}\text { COMPARZ } \\
\text { (pazopanib vs sunitinib) } \\
\text { Phase III, 1st line } \\
\text { NCT00720941 }\end{array}$ & Pazopanib & 554 & $\begin{array}{l}\text { Creatinine increase } \\
\text { Proteinuria }^{\mathrm{a}} \\
\text { Acute renal failure }^{\mathrm{a}} \\
\text { Hematuria }^{\mathrm{a}} \\
\text { Renal failure }^{\mathrm{a}}\end{array}$ & $\begin{array}{l}32 \\
18 \\
<1 \\
0.36 \\
<1\end{array}$ & $\begin{array}{l}1 \\
<1 \\
<1 \\
0.36 \\
<1\end{array}$ & {$[24]$} \\
\hline $\begin{array}{l}\text { TARGET } \\
\text { Phase III, 2nd line } \\
\text { NCT00073307 }\end{array}$ & Sorafenib & 451 & Renal failure $^{a}$ & 1.77 & 1.77 & {$[111,112]$} \\
\hline $\begin{array}{l}\text { INTORSECT } \\
\text { Phase III, post-cytokine } \\
\text { NCT00474786 }\end{array}$ & Sorafenib & 252 & $\begin{array}{l}\text { Creatinine increase }^{\mathrm{a}} \\
\text { Renal failure } \\
\text { Acute renal failure }^{\mathrm{a}}\end{array}$ & $\begin{array}{l}12.85 \\
1.61 \\
0.4\end{array}$ & $\begin{array}{l}\text { ND } \\
1.61 \\
0.4\end{array}$ & [113] \\
\hline $\begin{array}{l}\text { Phase II, post-cytokine } \\
\text { NCT00076011 }\end{array}$ & Axitinib & 52 & $\begin{array}{l}\text { Hematuria }^{\mathrm{a}} \\
\text { Acute renal failure }^{\mathrm{a}}\end{array}$ & $\begin{array}{l}9.62 \\
1.92\end{array}$ & $\begin{array}{l}1.92 \\
1.92\end{array}$ & [114] \\
\hline $\begin{array}{l}\text { Phase II, post-cytokine } \\
\text { NCT00569946 }\end{array}$ & Axitinib & 64 & $\begin{array}{l}\text { Proteinuria } \\
\text { Hematuria }^{\text {a }}\end{array}$ & $\begin{array}{l}63 \\
1.56\end{array}$ & $\begin{array}{l}9 \\
1.56\end{array}$ & [115] \\
\hline $\begin{array}{l}\text { AXIS } \\
\text { Phase III, 2nd line } \\
\text { NCT00678392 }\end{array}$ & Axitinib & 361 & $\begin{array}{l}\text { Creatinine increase } \\
\text { Proteinuria }\end{array}$ & $\begin{array}{l}55 \\
13\end{array}$ & $\begin{array}{l}0 \\
3\end{array}$ & {$[23,116]$} \\
\hline
\end{tabular}


Table 1 (continued)

\begin{tabular}{|c|c|c|c|c|c|c|}
\hline \multirow[t]{2}{*}{ Trial } & \multirow[t]{2}{*}{ Drug } & \multirow[t]{2}{*}{ Number of patients } & \multicolumn{4}{|l|}{ Renal related toxicities } \\
\hline & & & Type & $\begin{array}{l}\text { Overall, } \\
\text { any grade } \\
(\%)\end{array}$ & $\begin{array}{l}\text { Grades } \\
3-4 / \mathrm{SAE} \\
(\%)\end{array}$ & Refs. \\
\hline \multirow[t]{2}{*}{$\begin{array}{l}\text { Phase III, 1st or 2nd line } \\
\text { NCT00920816 }\end{array}$} & Axitinib & 192 (135 Asian pts) & $\begin{array}{l}\text { Creatinine increase (data } \\
\text { only for Asian pts) }\end{array}$ & 39.2 & 0.8 & [117-119] \\
\hline & & & $\begin{array}{l}\text { Proteinuria (data only for } \\
\text { Asian pts) }\end{array}$ & 20.7 & 5.2 & \\
\hline \multirow{3}{*}{$\begin{array}{l}\text { CABOSUN } \\
\text { Phase II, 1st line } \\
\text { NCT01835158 }\end{array}$} & Cabozantinib & 79 & Creatinine increase & 25 & 3 & {$[120-122]$} \\
\hline & & & Hematuria $^{a}$ & 2.56 & 2.56 & \\
\hline & & & Proteinuria $^{\mathrm{a}}$ & 7.69 & 1.28 & \\
\hline \multirow{2}{*}{$\begin{array}{l}\text { METEOR } \\
\text { Phase III, post-cytokine } \\
\text { NCT } 01865747\end{array}$} & Cabozantinib & 330 & Proteinuria & 12 & 2 & {$[123,124]$} \\
\hline & & & Creatinine increase & 5 & $<1$ & \\
\hline
\end{tabular}

$N D$ no data, $S A E$ serious adverse events

${ }^{a}$ Data from clinicaltrials.gov registry

mesangioproliferative glomerulonephritis, cryoglobulinemic glomerulonephritis, extracapillary proliferative glomerulonephritis [29], and immune complex-mediated focal glomerulonephritis [30] have also been reported. Patients receiving TKI's may also experience nausea, vomiting, and diarrhea, which can cause dehydration and, in serious cases, contribute to prerenal kidney failure [31]. The mechanisms of renal toxicity on the molecular level are complex. TKIs activate the endothelin-1 system and modulate the renin-angiotensin system, resulting in hypertension and microvascular dysfunction [32].

Moreover, podocytes-cells forming the filtration barrier in renal glomeruli-are involved in proteinuria's pathophysiology. Podocytes abundantly express VEGF and its receptors, maintaining these cells' physiological function and glomerular filtration membrane integrity. TKIs, by interfering with VEGF receptors' activity on the podocytes, impair the glomerular filtration barrier and, consequently, induce proteinuria and reduced glomerular filtration rate [33]. Some studies suggest that the TKI-mediated podocyte injury might be facilitated by tyrosine phosphorylation of nephrin, a protein expressed in podocytes critical for maintaining the integrity of the filtration barrier [34]. The loss of normal podocyte fenestration results in microvascular injury, capillary thrombosis, and renal glomeruli sclerotization, which may cause TMA. Affected patients develop proteinuria, hypertension, anemia, thrombocytopenia, and eventually renal failure. Proteinuria as a side effect of TKIs is not only caused by increased glomerular permeability. Still, it is also secondary to increased intraglomerular pressure that is an effect of arterial hypertension, another TKI side effect. Even though hypertension and proteinuria often occur simultaneously, it is not clear whether both of these side effects occur independently as an effect of VEGF blockage, or one of them is secondary to the other. Moreover, TKIs may induce acute renal failure through toxic injury of renal tubules or tumor lysis syndrome [33, 34].

\section{Management}

TKI-induced hypertension has been well documented in several studies as a predictor of favorable prognosis in metastatic RCC (mRCC) patients [20, 35]. However, data regarding TKI-induced renal function impairment as a prognostic factor for RCC patients are limited. In a retrospective analysis of Korean patients receiving sunitinib, the incidence of renal AEs, namely proteinuria, was associated with longer progression-free survival (PFS) [21]. A pooled secondary analysis of patients with $\mathrm{mRCC}$ treated with pazopanib and sunitinib in phase III randomized clinical trials showed that proteinuria, particularly grades $3 / 4$, was associated with improved overall survival (OS) (HR 0.53, 95\% CI 0.30-0.92) [36]. In a previous analysis, the development of new-onset hypercreatinemia during TKI treatment was related to a more favorable prognosis in OS and PFS [20]. These results suggest that the presence of renal AEs during TKI treatment should not necessitate treatment discontinuation, especially when the side effects are moderate. There are no evidencebased recommendations on the treatment of TKI-associated renal AEs. Most patients with proteinuria are treated with renin-angiotensin system blockers (angiotensin-converting enzyme inhibitors or angiotensin II receptor blockers); however, no interventional studies have been conducted to confirm the recommendation of this treatment for TKI-induced proteinuria. Isolated proteinuria is not an indication for dose reduction unless nephrotic-range (3.5 g or more per day) or edema, hyperlipidemia, and hypoalbuminemia occur [37]. Acute kidney injury, nephrotic range proteinuria, and TMA 
are generally considered reasons to discontinue therapy with TKIs [27, 38]. In TMA, anti-VEGF cessation halts further renal deterioration and enables at least partial recovery [39, 40]. Reintroduction of the drug allowing for continued antitumor treatment might be possible at lower doses; however, choosing an appropriate dose for reintroduction may be difficult. In an observational study, continued drug administration or reintroduction resulted in a more severe TMA recurrence in three of four patients requiring a maintenance dose of anti-VEGF agents [41]. Therefore, permanent drug discontinuation should be strongly considered in the case of TMA. It is important, that renal function parameters such as creatinine, blood urea nitrogen, baseline proteinuria, and estimated glomerular filtration rate (eGFR) are measured before initiating TKI treatment. Clinicians are also advised to check for proteinuria and renal function indices before each dose or therapy cycle.

\section{Patients with CKD or undergoing dialysis}

The tyrosine kinase inhibitors are primarily metabolized in the liver by the cytochrome CYP3A4, and their renal excretion does not exceed 23\% (Table 2). In population pharmacokinetic analyses, no correlation between TKI exposure and renal function was observed in subjects with mild, moderate, or severe renal impairment who were not on dialysis. These data indicate no need for initial dose adjustment in patients with mild to severe CKD, although caution is advised if creatinine clearance is lower than $30 \mathrm{ml} / \mathrm{min} / 1.73 \mathrm{~m} 2$ (Table 2).

Patients treated with TKIs for an extended time may present with declining renal function. Age-related renal dysfunction interferes and prevents determining causeeffect relation between TKI therapy and renal function [42]. A study by Khan et al. [43] reports that in patients treated with sorafenib or sunitinib who developed renal insufficiency during treatment, median serum creatinine clearance declines from $61.5 \mathrm{~mL} / \mathrm{min}$ to $39.2 \mathrm{~mL} / \mathrm{min}$ with the median time to $>30 \%$ serum creatinine concentration buildup of 4.6 months. In patients who developed renal insufficiency before starting treatment, median creatinine clearance was rather stable (median fall from $38.4 \mathrm{~mL} / \mathrm{min}$ to $36.2 \mathrm{~mL} / \mathrm{min}$ ) [43]. Renal insufficiency before the start of treatment does not necessarily increase the risk of kidney function deterioration. Still, in some studies, aggravation of pre-existing kidney impairment may comprise $66 \%$ of all renal insufficiencies [21]. Kidney injury that develops during treatment is a risk factor for progressive decline in renal function and increases the risk of dose reduction due to renal insufficiency [43].

The pharmacokinetics of sunitinib, sorafenib, and axitinib in patients with mild to severe CKD are similar to those observed in patients with normal renal function [44-46]. The pharmacokinetics of pazopanib in patients with impaired renal function has not been studied. In patients with $\mathrm{mRCC}$, CKD present at baseline or developed during treatment with sunitinib or sorafenib was not associated with unexpected toxicities [43]. Importantly, patients with $\mathrm{mRCC}$ and impaired renal function treated with anti-VEGF drugs do not differ in response rate, time to treatment failure, and OS from patients with normal renal function [47]. A retrospective study of 229 patients with $\mathrm{mRCC}$ treated with pazopanib demonstrated that renal function at initiation of therapy did

Table 2 Metabolism of targeted anticancer agents and management indications based on the drugs' summaries of product characteristics

\begin{tabular}{|c|c|c|c|c|c|}
\hline \multirow[t]{2}{*}{ Drug } & \multirow[t]{2}{*}{ Main way of metabolism } & \multirow{2}{*}{$\begin{array}{l}\text { Renal excretion of } \\
\text { drug and metabolites }\end{array}$} & \multicolumn{3}{|c|}{ Dose reduction required } \\
\hline & & & $\begin{array}{l}\text { Patients with mild to } \\
\text { moderate } \mathrm{CKD}^{\mathrm{a}}\end{array}$ & $\begin{array}{l}\text { Patients with } \\
\text { severe CKD }\end{array}$ & Patients on dialysis \\
\hline \multicolumn{6}{|l|}{ Tyrosine kinase inhibitors } \\
\hline Sunitinib [125] & Liver, CYP3A4 & $16 \%$ & No & No & No (ND) \\
\hline Sorafenib [126] & Liver, CYP3A4 & $19 \%$ & No & No & No (ND) \\
\hline Pazopanib [127] & Liver, CYP3A4 & $<4 \%$ & No & No (ND) & No (ND) \\
\hline Axitinib [128] & Liver, CYP3A4 & $23 \%$ & No & No & No (ND) \\
\hline \multicolumn{6}{|l|}{ mTOR inhibitors } \\
\hline Everolimus [129] & Liver, CYP3A4 & $5 \%$ & No & No (ND) & No (ND) \\
\hline Temsirolimus [130] & Liver, CYP3A4 & $4.6 \%$ & No (ND) & No (ND) & No (ND) \\
\hline \multicolumn{6}{|c|}{ Immune checkpoint inhibitors } \\
\hline Ipilimumab [131] & Proteolytic degradation & No & No & No & No (ND) \\
\hline Nivolumab [132] & Proteolytic degradation & No & No & No & No (ND) \\
\hline Pembrolizumab [133] & Proteolytic degradation & No & No & No (ND) & No (ND) \\
\hline Atezolizumab [134] & Proteolytic degradation & No & No & No (ND) & No (ND) \\
\hline
\end{tabular}

$C K D$ chronic kidney disease, $N D$ no data

${ }^{\mathrm{a}} 30-90 \mathrm{ml} / \mathrm{min} / 1.73 \mathrm{~m} 2 .{ }^{\mathrm{b}}<30 \mathrm{ml} / \mathrm{min} / 1.73 \mathrm{~m}^{2}$ 
not adversely affect pazopanib's safety and efficacy [48]. Therefore, impaired renal function should not prevent the initiation or continuation of anti-angiogenic therapies.

With the development and introduction of targeted therapies for RCC, TKIs were also studied in hemodialyzed (HD) patients. Studies in HD patients demonstrated no clearance of sunitinib, sorafenib, pazopanib, or axitinib from plasma by the dialyzer. The pharmacokinetics of these drugs is rarely influenced by dialysis [49-52]. Therefore, administration of these drugs may take place anytime, regardless of HD timing. Available data from larger studies of mRCC HD patients treated with TKIs are presented in Table 3. TKIs were generally well tolerated, with few reported AEs.

Nevertheless, a systematic review by Leonetti et al. [53] showed a higher incidence of sorafenib-related AEs in mRCC dialysis patients compared to the general mRCC population. Incidents of severe AEs such as subarachnoid hemorrhage resulting in the patient's death were also noted (Table 3). The median PFS of 10.9 and 9 months and OS of 18.4 and 12.5 months presented in expanded-access trials of sunitinib and sorafenib, respectively [54, 55], are comparable to those reported in HD patients (Table 3). Evidence from a small number of cases also suggests a good efficacy and tolerability of pazopanib and axitinib treatment in mRCC patients undergoing dialysis [56, 57]. At this time, there are no established evidence-based guidelines on the management of such patients. Based on the available literature, the initial dose adjustment of TKIs seems unnecessary in patients receiving dialysis (Table 2). Long-term HD patients have a higher risk of cardiovascular comorbidities and should be monitored closely, as cardiovascular events are likely to be more frequent in this population [49]. Therapy administration should be performed with caution, followed by increased surveillance of AEs and appropriate dose reduction if AEs occur. Most importantly, dialysis should not be regarded as a contraindication to this type of treatment.

\section{Renal toxicities of mTORis therapy}

\section{Incidence}

Inhibitors of mammalian target of rapamycin (mTORis) such as temsirolimus and everolimus are well-established options for treating $\mathrm{mRCC}$ in further lines after TKI failure. Commonly reported side effects with mTORis include stomatitis, rash, fatigue, asthenia, diarrhea, metabolic complications, infections, and noninfectious pneumonitis [58]. Adverse renal effects, such as AKI, have also been reported. In a meta-analysis of nine randomized clinical trials assessing renal toxicity of mTORis, all-grade AKI and high-grade AKI occurred in $15.7 \%$ and $4.2 \%$ of patients, respectively. Interestingly, the AKI incidence rates did not differ significantly between mTORis and other drugs tested in RCC randomized clinical trials [59]. In another meta-analysis, AKI was the second most common cause of fatal AEs in patients receiving mTORis for cancer, representing $5.7 \%$ of all study deaths [60]. The incidence of proteinuria in $\mathrm{mRCC}$ patients treated with mTORis has not been reported in the literature; however, it has been described in renal transplant recipients receiving everolimus [61].

\section{Mechanisms of nephrotoxicity}

The mTOR complex plays an important role in the process of kidney regeneration and recovery. Although mTOR activity is low or absent in the healthy kidney, it increases markedly after ischemia-reperfusion injury [62]. Inhibition of mTOR by rapamycin delayed renal recovery and repair after AKI in animal models but, importantly, renal function fully recovered after several days, despite continued treatment [63]. Everolimus was also shown to have antiproliferative effects and, through induction of autophagy, to aggravate tubular dysfunction during recovery from kidney injury in a rat model [64]. Biopsy-proven acute tubular necrosis after starting mTORis therapy was reported in a case series of four patients [65]. The effect of everolimus on tubular cells can be reflected by an accumulation of the cellular protein LC3 A in the urine, which might in the future prove to be a useful marker of AKI induced by mTOR inhibition [64].

Moreover, everolimus induced renal function deterioration and proteinuria by inhibiting the proliferative activity associated with reduced VEGF expression in a remnant kidney model. This mechanism may be particularly important in patients with RCC after nephrectomy [66]. Another potential mechanism for mTORis nephrotoxicity is based on the fact that rapamycin inhibits mTORC2, a multiprotein complex containing mTOR, which activates the Akt/PKB kinase [67]. Thus, mTORis inhibit the Akt pathway, which is essential for maintaining cell survival and signaling. It is still unclear whether mTORis cause renal dysfunction directly or through impairment of kidney repair in response to stress caused by other nephrotoxic factors $[65,66]$.

\section{Management}

ACEIs and ARBs are indicated in the treatment of mTORiassociated proteinuria [68]. Caution should be taken while administering ACEIs in combination with temsirolimus, as sporadic cases of angioneurotic edema have been reported in the drug's summary of product characteristics. If grade 3 renal toxic effects develop during mTORi therapy, treatment should be suspended and resumed upon renal function recovery. In AKI or grade 4 proteinuria, permanent discontinuation of treatment is generally recommended [38]. In a Korean retrospective study, the occurrence of AKI in RCC 


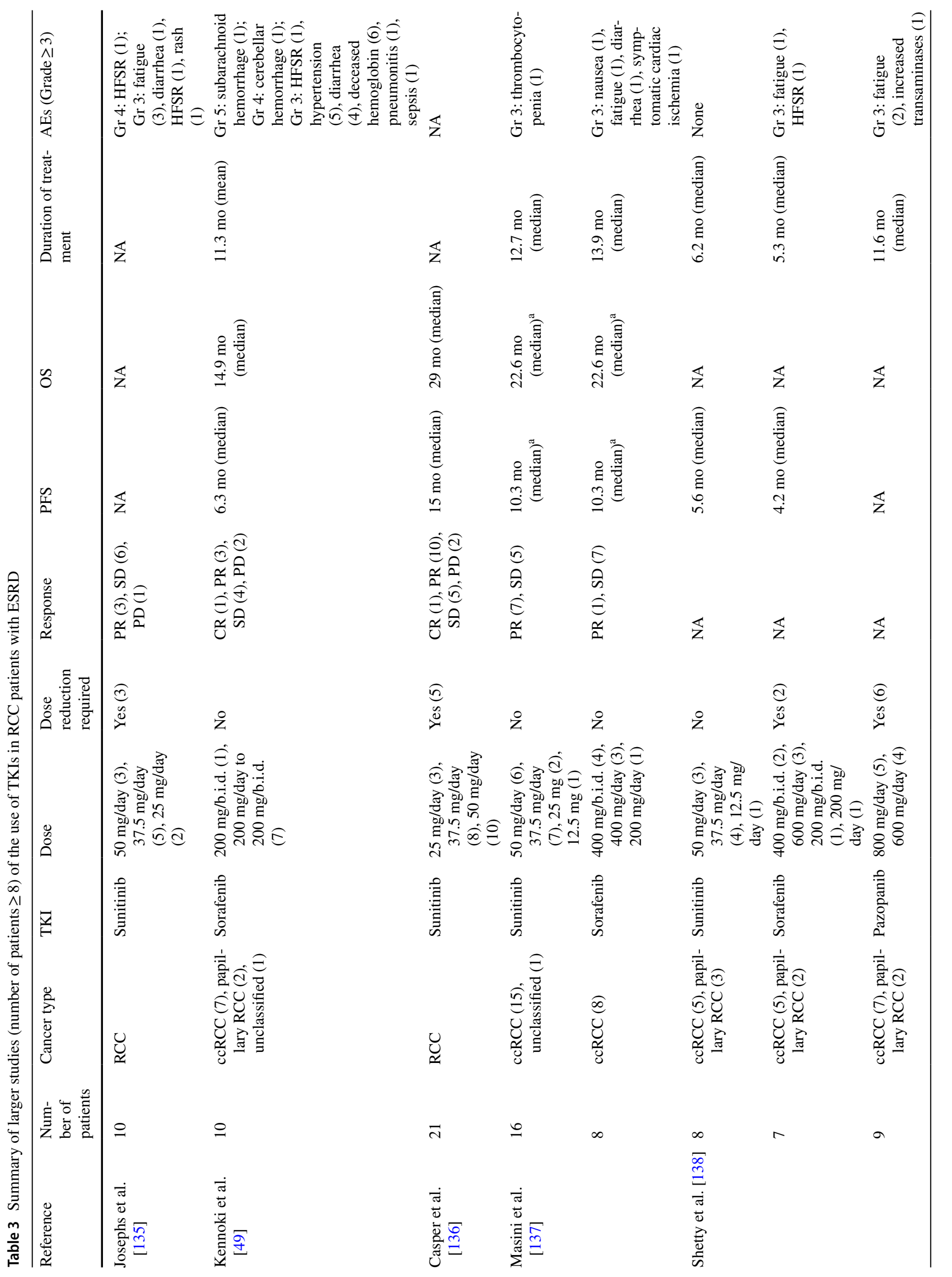




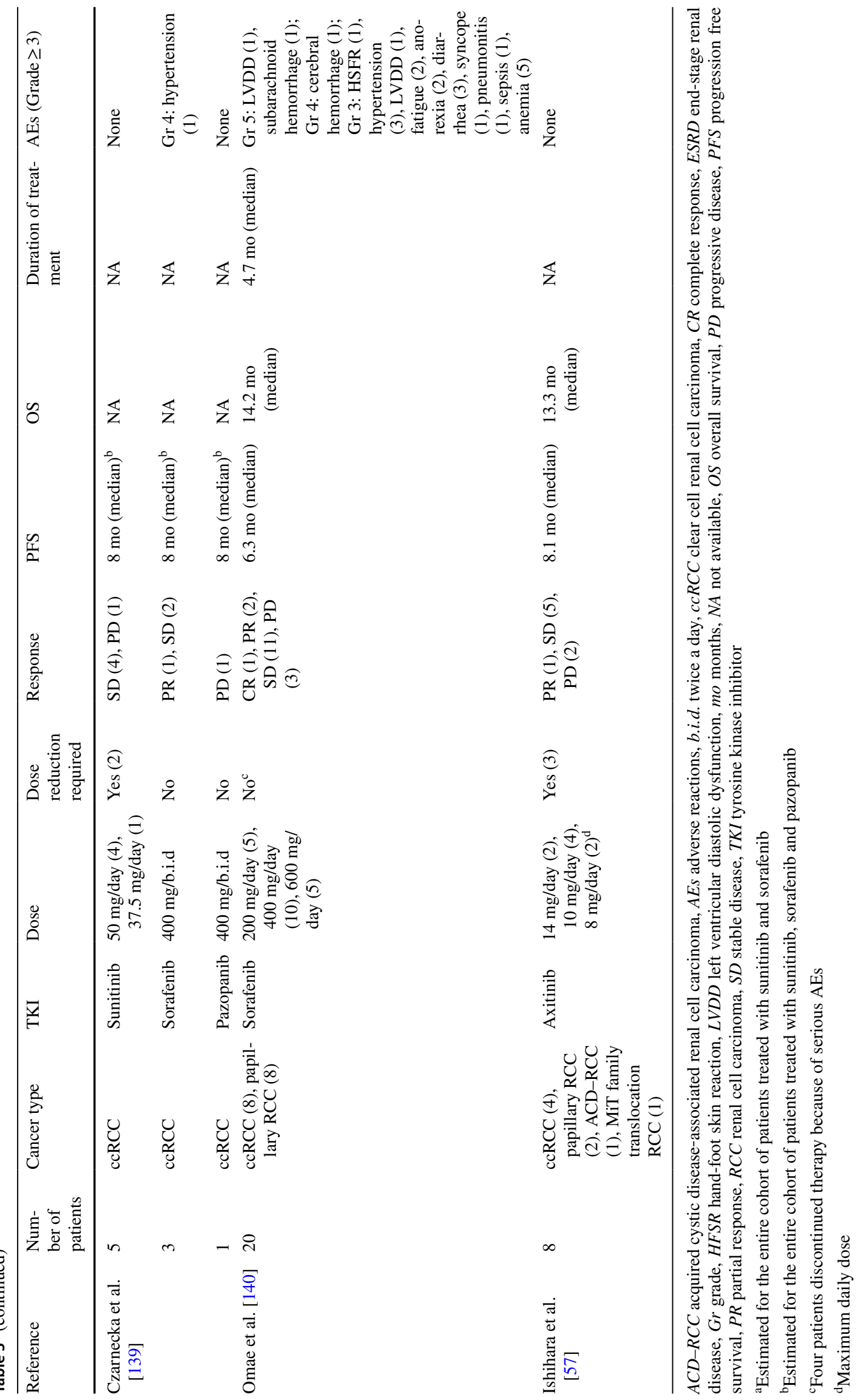


patients did not require everolimus discontinuation in 9 of 14 cases. The authors suggested that the treatment decision should be made via a multidisciplinary approach, including the assessment of oncological benefits of everolimus and other therapeutic options [69].

\section{Patients with CKD or undergoing dialysis}

mTORis such as temsirolimus and everolimus are metabolized mostly by the liver. In population pharmacokinetic analyses, creatinine clearance was not affected by the clearance of everolimus in patients with mild to moderate CKD. No clinical studies were conducted with temsirolimus in patients with decreased renal function (Table 2). However, considering their very small renal excretion, no dosage adjustment of everolimus or temsirolimus is recommended in patients with renal impairment.

RCC patients with impaired renal function are at a higher risk of developing AKI with mTORis. In the previously mentioned Korean study [69], AKI incidence in patients receiving everolimus increased as the baseline eGFR decreased. Moreover, baseline eGFR was an independent risk factor for the development of everolimus-associated AKI [69]. In a retrospective analysis of 18 patients with nondialysis dependent CKD and mRCC treated with mTORis, elevated creatinine level was noted in $77 \%$ of patients. The efficacy and safety of mTORis use were similar to patients with normal renal function [70].

mTORis do not require dose adjustment in hemodialyzed patients, as their blood concentration is not altered by dialysis [71, 72]. Table 4 summarizes available evidence of mTORis use in RCC patients on hemodialysis. Grade 3 AEs occurred in ten cases, and no grade 4 AEs were observed. The estimated median PFS and OS of 9.0 and 15.7 months, respectively, reported by Guida et al. in RCC patients on dialysis receiving everolimus [73], are in line with those reported in the phase III everolimus RECORD-1 study [74]. Therefore, mTORis seem to be an effective and safe treatment option for patients with $\mathrm{mRCC}$ and severe renal impairment requiring dialysis. Therefore, the use of mTORis should not be contraindicated in this subset of patients.

\section{Renal toxicities of immune checkpoint inhibitors}

\section{Incidence}

In the last years, ICPIs have become the standard first line of treatment in mRCC [75]. Among the drugs currently approved are cytotoxic $\mathrm{T}$ lymphocyte-associated protein 4 (CTLA-4) blocking antibodies (ipilimumab), programmed cell death protein 1 (PD-1) blocking antibodies (nivolumab, pembrolizumab), and PD-ligand 1 antibodies (atezolizumab). Several organ systems are affected by the use of ICPIs, including the central nervous system and cardiovascular, respiratory, musculoskeletal, and hematologic systems. However, the gastrointestinal tract, endocrine glands, skin, and liver seem to be the most commonly involved [76].

Adverse renal effects of ICPIs are rare but increasingly described. They include AKI, proteinuria, and electrolyte abnormalities. The frequency of immune checkpoint inhibitor-associated AKI (ICPI-AKI) does not seem to differ significantly between CTLA-4 and PD1 targeting drugs [77]. A recent review of 48 clinical trials involving 11,482 patients treated with PD-1 inhibitors reported a pooled relative risk for AKI of 4.19 (95\% confidence interval, 1.57-11.18) when compared with non-nephrotoxic controls and an estimated incidence of $2.2 \%$ [78]. These numbers are likely underestimated, as they reflect data obtained in clinical trials, which might not be applicable in a standard clinical setting.

\section{Combination therapy}

In recent years, clinical investigations have focused on two types of combination regimens: combinations of ICPIs and combinations of ICPIs and TKIs. In April 2018, the FDA approved the combination therapy of ipilimumab and nivolumab to treat intermediate or poor-risk advanced RCC. In the CheckMate 214 study evaluating the combination of nivolumab plus ipilimumab as first-line treatment for advanced RCC, increased blood creatinine was present in $7.3 \%$ of patients. AKI occurred in $2.2 \%$ of patients treated with combination therapy [79]. In an analysis of data from phase II and III clinical trials, the incidence of ICPI-AKI was estimated to be higher in patients receiving combination ipilimumab/nivolumab therapy (4.9\%) compared to monotherapy (pembrolizumab, 1.4\%, nivolumab, $1.9 \%$, ipilimumab, 2\%) [80]. Recently, positive results of studies assessing outcomes of ICPIs and TKIs combinations led to FDA approvals of pembrolizumab plus axitinib and avelumab plus axitinib in first-line treatment of advanced RCC. In a phase III JAVELIN Renal 101 study investigating avelumab plus axitinib for advanced RCC, no renal AEs were reported with the data cutoff of $\geq 10 \%$ for any grade events and $\geq 5 \%$ for grade $\geq 3$ events [81]. In an extended followup from a phase III study of pembrolizumab plus axitinib in RCC treatment (KEYNOTE-426), AKI was present in 5 of 429 patients (1.2\%) and nephritis in 8 patients (1.9\%) [82]. Importantly, in both studies, combination therapy was not associated with a higher incidence of AEs than sunitinib alone.

Additionally, in a phase I study of mRCC patients treated with nivolumab combined with sunitinib or pazopanib (CheckMate 016 study), treatment was associated with increased blood creatinine in $33.3 \%$ and $5 \%$, respectively. 


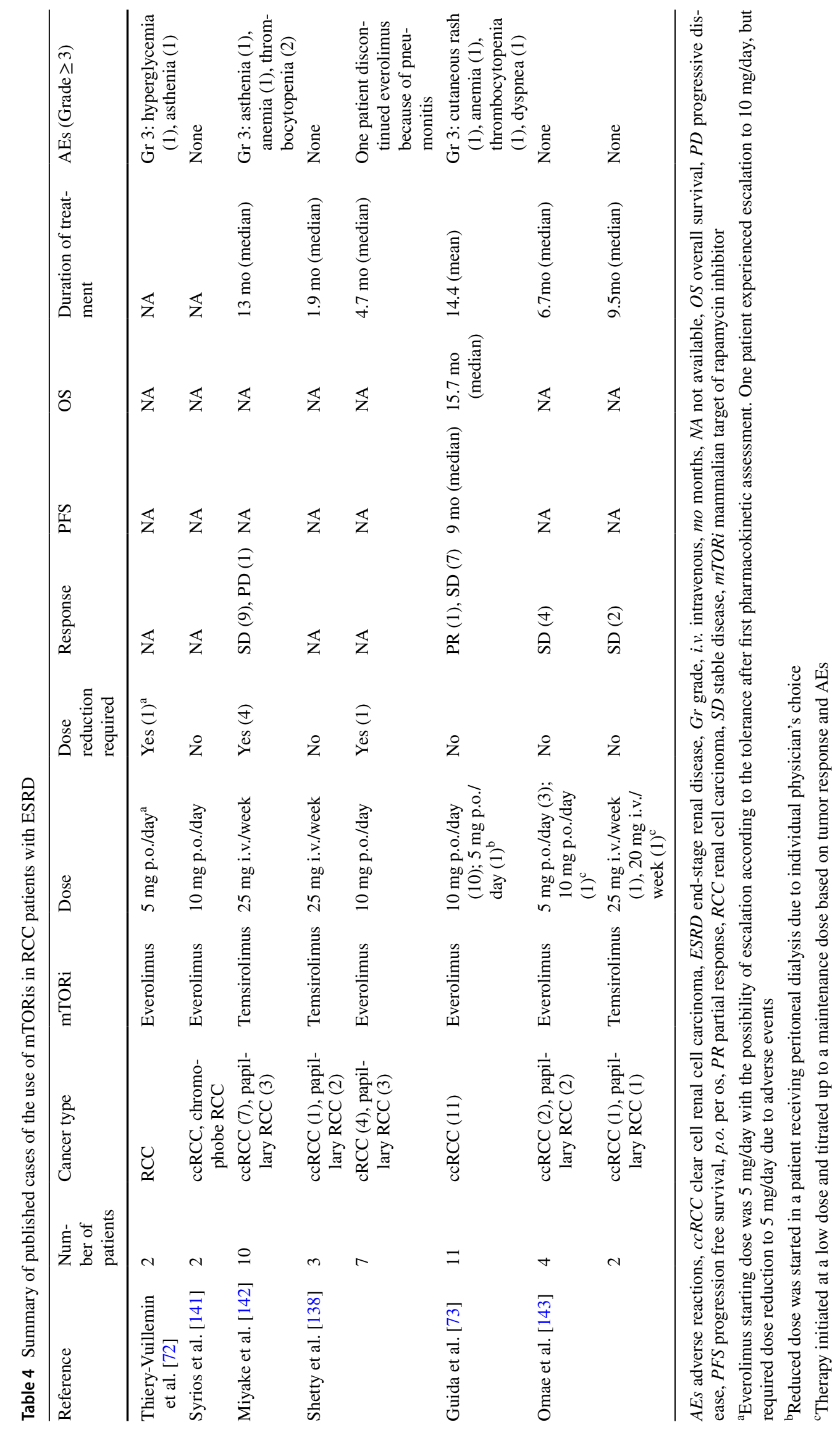


AKI leading to treatment discontinuation occurred in $9.1 \%$ of patients in the study's nivolumab plus sunitinib arm [83]. Glomerulonephritis was also reported in a series of three patients treated with immunotherapy and TKIs [84]. Combinations of ICPIs and TKIs are currently tested in various clinical trials; they offer promising results regarding improved clinical outcomes while maintaining tolerable side effect profiles resulting in wider use in the nearest future. Currently available data do not suggest that combination therapy is associated with previously unknown toxicities. Considering these data and renal AEs observed in monotherapy, special caution and close monitoring of renal function might be necessary to prevent and early detect possible toxicities from combination therapy.

\section{Mechanisms of nephrotoxicity}

Acute tubulointerstitial nephritis (ATIN), either alone or other kidney lesions such as acute tubular injury or glomerular disease, is the most common histopathologic finding ICPI-AKI on kidney biopsy [85]. In the largest study of patients with ICPI-AKI up to date, ATIN was the dominant lesion in $93 \%$ of the 60 patients biopsied [86]. In a study by Mamlouk et al., ATIN was present in 14 of 16 cases; however, nine of these cases were associated with glomerular disease, including pauci-immune glomerulonephritis, $\operatorname{IgA}$ nephropathy, and other pathologies [87].

The precise mechanisms of ICPI-AKI are not yet known, with two hypotheses suggested by most researchers [80, 88-90]. Through the inhibition of specific receptors (e.g., CTLA-4, PD-1) or their ligands (PD-L1), ICPIs "release the brakes" of the immune system, allowing T-cells to become activated and exert antitumor activity [91]. Mice with knockout CTLA-4 or PD-1 genes have been shown to develop autoimmunity against specific organs, including glomerulonephritis, driven by the emergence of antigenspecific T-cells targeting self-antigens [92, 93]. Blockade of PD- 1 or CTLA-4 with ICPIs in humans may lead to a loss of tolerance against endogenous kidney antigens and cause cytotoxic injury to the kidney. The exact antigen has not yet been identified but is possibly expressed by tubular cells based on ATIN's dominant finding on biopsy. Alternatively, it is also possible that ICPIs lead to activation of memory T-cells previously primed by other haptens causing ATIN, such as proton pump inhibitors (PPIs) or nonsteroidal antiinflammatory drugs (NSAIDs). In support of this theory, in a recent large multicentre study, nearly $70 \%$ of patients with ICPI-AKI received a potential ATIN-causing medication, including PPIs in over $50 \%$ of cases. Concomitant use of PPIs was also an independent risk factor for the development of ICPI-AKI. [86].

\section{Management}

The European Society for Medical Oncology (ESMO) guidelines recommend that serum sodium, potassium, creatinine, and urea should be measured before every infusion of ICPIs. Baseline urinalysis, with quantification of proteinuria or microalbuminuria if present, before initiation of ICPI therapy is also advised [94]. Baseline assessment and monitoring of the number of leukocytes in urinalysis could also be helpful, since sterile pyuria and/or leukocyte casts may suggest an inflammatory kidney lesion, although they are not specific for ATIN diagnosis [95]. If renal dysfunction develops during treatment, alternative AKI etiologies, such as hypovolemia, infection, contrast-enhanced nephropathy, and urinary tract obstruction, should be initially ruled out. Immunotherapy should be temporarily discontinued until further clarification of the cause of AKI. The role of kidney biopsy in patients who developed AKI while undergoing ICPI treatment is debated. American Society of Clinical Oncology (ASCO) and ESMO guidelines recommend proceeding directly with immunosuppressive therapy without a kidney biopsy unless an alternative cause of AKI is suspected [96, 97].

Once the diagnosis of ICPI-AKI is made, the discontinuation of ICPI therapy and glucocorticoid administration is generally recommended. Table 5 summarizes the published guidelines for the management of ICPI-related nephritis [96, 97]. In a multicenter study of 138 patients, this approach was associated with partial or complete kidney function recovery in $95 \%$ of cases [86]. Considering the potential influence of concomitant medications in the pathogenesis of ICPI-AKI, drugs that are known to induce ATIN, such as PPIs or NSAIDs, should be recognized and discontinued if possible [98]. Most authors also suggest that patients developing initial ICPI-AKI episode can be safely rechallenged with ICPIs once kidney function improves and corticosteroid administration is complete or nearly complete. Observational data support that statement. Out of 31 patients rechallenged with an ICPI after the initial episode of ICPI-AKI only 7 (23\%) experienced recurrent AKI, 6 of whom had complete or partial renal recovery [86].

\section{Patients with CKD or undergoing dialysis}

Underlying kidney disease may cause significant difficulties in the treatment of RCC patients with ICPIs. Most clinical trials do not include patients with moderate to severe kidney failure. Thus, ICPIs have not been widely studied in patients with renal failure or end-stage renal disease on dialysis. Because ICPIs undergo proteolytic degradation and not renal excretion, the lower glomerular filtration rate is not expected to impact their pharmacokinetics. In fact, in the case of nivolumab, the pharmacokinetics is linear in 
Table 5 Grading of ICPI-related nephritis and management by severity

\begin{tabular}{|c|c|}
\hline Grade $^{\mathrm{a}}$ & Management \\
\hline $\mathrm{G} 1:$ creatinine $>\mathrm{ULN}-1.5 \times \mathrm{ULN}$ & $\begin{array}{l}\text { Continue ICPI } \\
\text { Discontinue nephrotoxic drugs } \\
\text { Monitor renal function and proteinuria } \\
\text { Exclude alternative causes (dehydration, recent i.v. contrast, UTI, } \\
\text { medications, obstruction, hypotension, hypertension) }\end{array}$ \\
\hline G2: creatinine $>1.5-3.0 \times$ baseline $;>1.5-3.0 \times \mathrm{ULN}$ & $\begin{array}{l}\text { Withhold ICPI } \\
\text { Discontinue nephrotoxic drugs } \\
\text { Ensure hydration } \\
\text { Monitor renal function and proteinuria } \\
\text { Consult nephrologist } \\
\text { Consider biopsy } \\
\text { Exclude alternative causes (as above) } \\
\text { Initiate steroids }(0.5-1 \mathrm{mg} / \mathrm{kg} / \text { day oral prednisolone or equivalent) }\end{array}$ \\
\hline G3: creatinine $>3.0 \times$ baseline $;>3.0-6.0 \times \mathrm{ULN}$ & $\begin{array}{l}\text { Admit patient for monitoring and fluid balance } \\
\text { Withhold ICPI, consider permanent discontinuation } \\
\text { Discontinue nephrotoxic drugs } \\
\text { Monitor renal function and proteinuria } \\
\text { Consult nephrologist } \\
\text { Consider biopsy } \\
\text { Evaluate alternative causes (as above) } \\
\text { Initiate steroids ( } 1-2 \mathrm{mg} / \mathrm{kg} / \text { day i.v. prednisolone or equivalent) }\end{array}$ \\
\hline G4: creatinine $>6.0 \times \mathrm{ULN}$ & $\begin{array}{l}\text { As grade } 3 \\
\text { Treat in a center where renal replacement therapy is available }\end{array}$ \\
\hline
\end{tabular}

ICPI immune checkpoint inhibitor, i.v. intravenous, $U L N$ upper limit of normal, UTI urinary tract infection

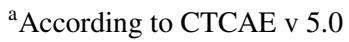

the dose range of 0.1 to $10 \mathrm{mg} / \mathrm{kg}$. There is no relationship between renal function status and pharmacokinetics [99]. In the IMvigor210 phase II trial of atezolizumab for cisplatinineligible urothelial carcinoma, $70 \%$ of patients had eGFR between 30 and $60 \mathrm{ml} / \mathrm{min}$, a comparable response rate and no loss in median eGFR was reported [100].

Considering the large molecular weights of ICPIs, drug filtration through the renal glomeruli or dialysis pores is unlikely. There are currently few published data on the use of ICPIs in patients with ESRD on hemodialysis (Table 6). Apart from nivolumab, other ICPIs have not been studied in this group of patients. Of the 20 described cases, in $80 \%$ of patients the treatment resulted in partial response or stable disease. Four grade 3 immune-related adverse events (irAEs) were observed, and no grade 4 irAEs have been reported up to date. Despite the small sample size, Tachibana et al. revealed no significant differences between the ESRD and non-ESRD groups in terms of PFS and OS [101]. The presented evidence suggests that renal impairment or ESRD may not be a contraindication for ICPI use in RCC patients.

\section{Conclusions}

Renal toxicity of targeted anticancer therapies represents an increasingly recognized problem for clinicians involved in treating patients with mRCC. As these AEs can lead to dose reductions or interruption of treatment, which might have a negative effect on the patient's survival, correct recognition and management of specific toxic effects are especially important.

There are several reasons why the relationships between targeted agents and the kidneys remain largely unexplored. Large randomized, controlled, phase III trials do not enroll patients with reduced kidney function; renal AEs are often not reported; the methodology and terminology differ across oncological trials (for example, definitions of creatinine elevation, CKD, or AKI); and most reports of patients on hemodialysis involve only single cases or small case series. Furthermore, direct comparison of PFS and OS is often not possible since reported data include the usage of drugs in various lines of therapy, differing starting doses, and subsequent dose escalation or reduction schemes.

Careful design of clinical trials focusing on renal toxic effects should shed more light on a group of patients for whom targeted therapies are a viable first- and second-line option. Further studies are needed to establish treatment guidelines for patients with impaired renal function and/or treated with chronic dialysis.

Because of the complex relationship between cancer, kidneys, and novel therapeutic agents, close collaboration between clinical oncologists, urologists, and nephrologists is crucial. The emergence of effective targeted therapies for mRCC significantly improved patients' prognoses, at 


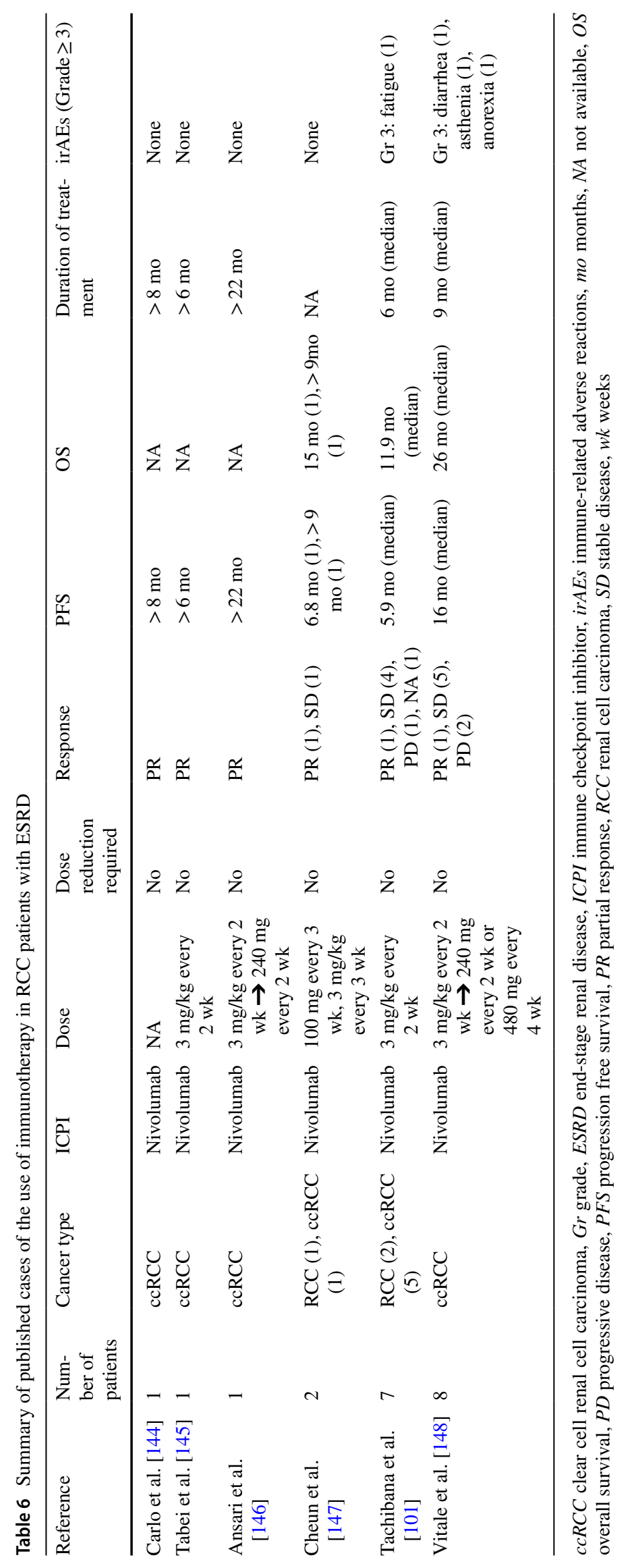


the cost of a whole new spectrum of renal adverse events that differ from those observed with conventional cytotoxic chemotherapy. Therefore, nephrologists should become acquainted with various aspects of cancer care, including the biology of RCC and molecular mechanisms of action of novel anticancer drugs. Onconephrology is an evolving and expanding subspecialty that relies on a multidisciplinary approach necessary to provide cutting-edge care for RCC patients with kidney impairment $[102,103]$.

This analysis highlights that patients with mRCC, including those on hemodialysis, generally benefit from targeted treatment in PFS and OS. Renal toxicities of targeted therapies differ in incidence but are generally mild to moderate in severity and can be managed effectively. The occurrence of AEs should not necessarily result in treatment discontinuation, and even if that decision is made, treatment can be resumed in specific situations. That said, therapy selection, administration, and toxicity management in $\mathrm{mRCC}$ patients undergoing dialysis should be performed with caution and increased monitoring of AEs. Close cooperation between oncologists and nephrologists in managing renal toxic effects should be encouraged to improve patients' outcome.

Funding This work was supported by subsidy from Ministry of Science and Higher Education of participating institutions.

\section{Declarations}

Conflict of interest $\mathrm{AB}$ has received a travel grant from Novartis and honoraria from Janssen. PS has received travel grants from MSD, Roche, and Pierre Fabre. AMC has received travel grants and honoraria from BMS, MSD, Roche, and Novartis. $€ M$ and ACJ declare no conflict of interest.

Ethical approval This article does not contain any studies with human participants or animals performed by any of the authors.

Open Access This article is licensed under a Creative Commons Attribution 4.0 International License, which permits use, sharing, adaptation, distribution and reproduction in any medium or format, as long as you give appropriate credit to the original author(s) and the source, provide a link to the Creative Commons licence, and indicate if changes were made. The images or other third party material in this article are included in the article's Creative Commons licence, unless indicated otherwise in a credit line to the material. If material is not included in the article's Creative Commons licence and your intended use is not permitted by statutory regulation or exceeds the permitted use, you will need to obtain permission directly from the copyright holder. To view a copy of this licence, visit http://creativecommons.org/licenses/by/4.0/.

\section{References}

1. Siegel RL, Miller KD (2020) Jemal A (2020) Cancer statistics. CA Cancer J Clin 70(1):7-30. https://doi.org/10.3322/caac. 21590

2. Macleod LC, Hotaling JM, Wright JL, Davenport MT, Gore JL, Harper J, White E (2013) Risk factors for renal cell carcinoma in the VITAL study. J Urol 190(5):1657-1661. https://doi.org/ 10.1016/j.juro.2013.04.130

3. Capitanio U, Bensalah K, Bex A, Boorjian SA, Bray F, Coleman J, Gore JL, Sun M, Wood C, Russo P (2019) Epidemiology of renal cell carcinoma. Eur Urol 75(1):74-84. https://doi.org/10. 1016/j.eururo.2018.08.036

4. Joh HK, Willett WC, Cho E (2011) Type 2 diabetes and the risk of renal cell cancer in women. Diabetes Care 34(7):1552-1556. https://doi.org/10.2337/dc11-0132

5. Huang WC, Levey AS, Serio AM, Snyder M, Vickers AJ, Raj GV, Scardino PT, Russo P (2006) Chronic kidney disease after nephrectomy in patients with renal cortical tumours: a retrospective cohort study. Lancet Oncol 7(9):735-740. https://doi. org/10.1016/S1470-2045(06)70803-8

6. Kompotiatis P, Thongprayoon C, Manohar S, Cheungpasitporn W, Gonzalez Suarez ML, Craici IM, Mao MA, Herrmann SM (2019) Association between urologic malignancies and endstage renal disease: a meta-analysis. Nephrology (Carlton) 24(1):65-73. https://doi.org/10.1111/nep.13209

7. Chewcharat A, Thongprayoon C, Bathini T, Aeddula NR, Boonpheng B, Kaewput W, Watthanasuntorn K, Lertjitbanjong P, Sharma K, Torres-Ortiz A, Leeaphorn N, Mao MA, Khoury NJ, Cheungpasitporn W (2019) Incidence and mortality of renal cell carcinoma after kidney transplantation: a meta-analysis. J Clin Med 8(4):530. https://doi.org/10.3390/ jcm8040530

8. Dy GW, Gore JL, Forouzanfar MH, Naghavi M, Fitzmaurice C (2017) Global burden of urologic cancers, 1990-2013. Eur Urol 71(3):437-446. https://doi.org/10.1016/j.eururo.2016.10.008

9. Neuzillet Y, Tillou X, Mathieu R, Long JA, Gigante M, Paparel P, Poissonnier L, Baumert H, Escudier B, Lang H, Rioux-Leclercq N, Bigot P, Bernhard JC, Albiges L, Bastien L, Petit J, Saint F, Bruyere F, Boutin JM, Brichart N, Karam G, Branchereau J, Ferriere JM, Wallerand H, Barbet S, Elkentaoui H, Hubert J, Feuillu B, Theveniaud PE, Villers A, Zini L, Descazeaux A, Roupret M, Barrou B, Fehri K, Lebret T, Tostain J, Terrier JE, Terrier N, Martin L, Dugardin F, Galliot I, Staerman F, Azemar MD, Irani J, Tisserand B, Timsit MO, Sallusto F, Rischmann P, Guy L, Valeri A, Deruelle C, Azzouzi AR, Chautard D, Mejean A, Salomon L, Rigaud J, Pfister C, Soulie M, Kleinclauss F, Badet L, Patard JJ, Comite de Transplantation de l'Association Francaise dU, Comite de Cancerologie de l'Association Francaise dU (2011) Renal cell carcinoma (RCC) in patients with end-stage renal disease exhibits many favourable clinical, pathologic, and outcome features compared with RCC in the general population. Eur Urol 60(2):366-373. https://doi.org/10.1016/j.eururo.2011. 02.035

10. Chen K, Huang HH, Aydin H, Tan YH, Lau WK, Cheng CW, Yuen JS (2015) Renal cell carcinoma in patients with end-stage renal disease is associated with more favourable histological features and prognosis. Scand J Urol 49(3):200-204. https://doi.org/ 10.3109/21681805.2015.1019561

11. Tsuzuki T, Iwata H, Murase Y, Takahara T, Ohashi A (2018) Renal tumors in end-stage renal disease: a comprehensive review. Int J Urol 25(9):780-786. https://doi.org/10.1111/iju.13759

12. Kim CS, Bae EH, Ma SK, Kweon SS, Kim SW (2014) Impact of partial nephrectomy on kidney function in patients with renal 
cell carcinoma. BMC Nephrol 15:181. https://doi.org/10.1186/ 1471-2369-15-181

13. Schmid M, Krishna N, Ravi P, Meyer CP, Becker A, Dalela D, Sood A, Chun FK, Kibel AS, Menon M, Fisch M, Trinh QD, Sun M (2016) Trends of acute kidney injury after radical or partial nephrectomy for renal cell carcinoma. Urol Oncol 34 (7):293 e291-293-e210. https://doi.org/10.1016/j.urolonc.2016.02.018

14. Grimaldi G, Reuter V, Russo P (1998) Bilateral non-familial renal cell carcinoma. Ann Surg Oncol 5(6):548-552. https://doi. org/10.1007/BF02303649

15. Janzen NK, Kim HL, Figlin RA, Belldegrun AS (2003) Surveillance after radical or partial nephrectomy for localized renal cell carcinoma and management of recurrent disease. Urol Clin N Am 30(4):843-852. https://doi.org/10.1016/s0094-0143(03) 00056-9

16. Cosmai L, Porta C, Perazella MA, Launay-Vacher V, Rosner MH, Jhaveri KD, Floris M, Pani A, Teuma C, Szczylik CA, Gallieni M (2018) Opening an onconephrology clinic: recommendations and basic requirements. Nephrol Dial Transplant 33(9):1503-1510. https://doi.org/10.1093/ndt/gfy188

17. Motzer RJ, Hutson TE, Tomczak P, Michaelson MD, Bukowski RM, Rixe O, Oudard S, Negrier S, Szczylik C, Kim ST, Chen I, Bycott PW, Baum CM, Figlin RA (2007) Sunitinib versus interferon alfa in metastatic renal-cell carcinoma. $\mathrm{N}$ Engl J Med 356(2):115-124. https://doi.org/10.1056/NEJMoa065044

18. Motzer RJ, Hutson TE, Tomczak P, Michaelson MD, Bukowski RM, Oudard S, Negrier S, Szczylik C, Pili R, Bjarnason GA, Garcia-del-Muro X, Sosman JA, Solska E, Wilding G, Thompson JA, Kim ST, Chen I, Huang X, Figlin RA (2009) Overall survival and updated results for sunitinib compared with interferon alfa in patients with metastatic renal cell carcinoma. J Clin Oncol 27(22):3584-3590. https://doi.org/10.1200/JCO.2008.20.1293

19. Zhu X, Stergiopoulos K, Wu S (2009) Risk of hypertension and renal dysfunction with an angiogenesis inhibitor sunitinib: systematic review and meta-analysis. Acta Oncol 48(1):9-17. https://doi.org/10.1080/02841860802314720

20. Czarnecka AM, Sobczuk P, Korniluk J, Spychalska M, Bogusz K, Owczarek A, Brodziak A, Labochka D, Moszczuk B, Szczylik C (2017) Long-term response to sunitinib: everolimus treatment in metastatic clear cell renal cell carcinoma. Future Oncol 13(1):31-49. https://doi.org/10.2217/fon-2016-0355

21. Baek SH, Kim H, Lee J, Kim DK, Oh KH, Kim YS, Han JS, Kim TM, Lee SH, Joo KW (2014) Renal adverse effects of sunitinib and its clinical significance: a single-center experience in Korea. Korean J Intern Med 29(1):40-48. https://doi.org/10.3904/kjim. 2014.29.1.40

22. Gupta S, Parsa V, Heilbrun LK, Smith DW, Dickow B, Heath E, Vaishampayan U (2011) Safety and efficacy of molecularly targeted agents in patients with metastatic kidney cancer with renal dysfunction. Anticancer Drugs 22(8):794-800. https://doi. org/10.1097/CAD.0b013e328346af0d

23. Rini BI, Escudier B, Tomczak P, Kaprin A, Szczylik C, Hutson TE, Michaelson MD, Gorbunova VA, Gore ME, Rusakov IG, Negrier S, Ou YC, Castellano D, Lim HY, Uemura H, Tarazi J, Cella D, Chen C, Rosbrook B, Kim S, Motzer RJ (2011) Comparative effectiveness of axitinib versus sorafenib in advanced renal cell carcinoma (AXIS): a randomised phase 3 trial. Lancet 378(9807):1931-1939. https://doi.org/10.1016/S0140-6736(11) 61613-9

24. Motzer RJ, Hutson TE, Cella D, Reeves J, Hawkins R, Guo J, Nathan P, Staehler M, de Souza P, Merchan JR, Boleti E, Fife K, Jin J, Jones R, Uemura H, De Giorgi U, Harmenberg U, Wang J, Sternberg CN, Deen K, McCann L, Hackshaw MD, Crescenzo R, Pandite LN, Choueiri TK (2013) Pazopanib versus sunitinib in metastatic renal-cell carcinoma. N Engl J Med 369(8):722-731. https://doi.org/10.1056/NEJMoa1303989

25. Miyake H, Muramaki M, Imai S, Harada K, Fujisawa M (2016) Changes in renal function of patients with metastatic renal cell carcinoma during treatment with molecular-targeted agents. Target Oncol 11(3):329-335. https://doi.org/10.1007/ s11523-015-0395-4

26. Zhang W, Feng LJ, Teng F, Li YH, Zhang X, Ran YG (2020) Incidence and risk of proteinuria associated with newly approved vascular endothelial growth factor receptor tyrosine kinase inhibitors in cancer patients: an up-to-date meta-analysis of randomized controlled trials. Expert Rev Clin Pharmacol 13(3):311320. https://doi.org/10.1080/17512433.2020.1734450

27. Izzedine H, Massard C, Spano JP, Goldwasser F, Khayat D, Soria JC (2010) VEGF signalling inhibition-induced proteinuria: mechanisms, significance and management. Eur J Cancer 46(2):439-448. https://doi.org/10.1016/j.ejca.2009.11.001

28. Usui J, Glezerman IG, Salvatore SP, Chandran CB, Flombaum CD, Seshan SV (2014) Clinicopathological spectrum of kidney diseases in cancer patients treated with vascular endothelial growth factor inhibitors: a report of 5 cases and review of literature. Hum Pathol 45(9):1918-1927. https://doi.org/10.1016/j. humpath.2014.05.015

29. Stylianou K, Lioudaki E, Papadimitraki E, Kokologiannakis G, Kroustalakis N, Liotsi C, Giannakakis K, Georgoulias V, Daphnis E (2011) Crescentic glomerulonephritis associated with vascular endothelial growth factor (VEGF) inhibitor and bisphosphonate administration. Nephrol Dial Transplant 26(5):1742-1745. https://doi.org/10.1093/ndt/gfr093

30. Rolleman EJ, Weening J, Betjes MGH (2009) Acute nephritic syndrome after anti-VEGF therapy for renal cell carcinoma. Nephrol Dial Transplant 24(6):2002-2003. https://doi.org/10. 1093/ndt/gfp140

31. Schwandt A, Wood LS, Rini B, Dreicer R (2009) Management of side effects associated with sunitinib therapy for patients with renal cell carcinoma. Onco Targets Ther 2:51-61. https://doi.org/ 10.2147/ott.s4052

32. Kappers MH, van Esch JH, Sluiter W, Sleijfer S, Danser AH, van den Meiracker AH (2010) Hypertension induced by the tyrosine kinase inhibitor sunitinib is associated with increased circulating endothelin-1 levels. Hypertension 56(4):675-681. https://doi.org/ 10.1161/HYPERTENSIONAHA.109.149690

33. Schrijvers BF, Flyvbjerg A, De Vriese AS (2004) The role of vascular endothelial growth factor (VEGF) in renal pathophysiology. Kidney Int 65(6):2003-2017. https://doi.org/10.1111/j. 1523-1755.2004.00621.x

34. Simons M, Schwarz K, Kriz W, Miettinen A, Reiser J, Mundel P, Holthofer H (2001) Involvement of lipid rafts in nephrin phosphorylation and organization of the glomerular slit diaphragm. Am J Pathol 159(3):1069-1077. https://doi.org/10.1016/S00029440(10)61782-8

35. Liu Y, Zhou L, Chen Y, Liao B, Ye D, Wang K, Li H (2019) Hypertension as a prognostic factor in metastatic renal cell carcinoma treated with tyrosine kinase inhibitors: a systematic review and meta-analysis. BMC Urol 19(1):49. https://doi.org/10.1186/ s12894-019-0481-5

36. Sorich MJ, Rowland A, Kichenadasse G, Woodman RJ, Mangoni AA (2016) Risk factors of proteinuria in renal cell carcinoma patients treated with VEGF inhibitors: a secondary analysis of pooled clinical trial data. Br J Cancer 114(12):1313-1317. https://doi.org/10.1038/bjc.2016.147

37. Alasker A, Meskawi M, Sun M, Ismail S, Hanna N, Hansen J, Tian Z, Bianchi M, Perrotte P, Karakiewicz PI (2013) A contemporary update on rates and management of toxicities of targeted 
therapies for metastatic renal cell carcinoma. Cancer Treat Rev 39(4):388-401. https://doi.org/10.1016/j.ctrv.2012.12.006

38. Porta C, Cosmai L, Gallieni M, Pedrazzoli P, Malberti F (2015) Renal effects of targeted anticancer therapies. Nat Rev Nephrol 11(6):354-370. https://doi.org/10.1038/nrneph.2015.15

39. Eremina V, Jefferson JA, Kowalewska J, Hochster H, Haas M, Weisstuch J, Richardson C, Kopp JB, Kabir MG, Backx PH, Gerber HP, Ferrara N, Barisoni L, Alpers CE, Quaggin SE (2008) VEGF inhibition and renal thrombotic microangiopathy. N Engl J Med 358(11):1129-1136. https://doi.org/10.1056/NEJMoa0707 330

40. Bollee G, Patey N, Cazajous G, Robert C, Goujon JM, Fakhouri F, Bruneval P, Noel LH, Knebelmann B (2009) Thrombotic microangiopathy secondary to VEGF pathway inhibition by sunitinib. Nephrol Dial Transpl 24(2):682-685. https://doi.org/ 10.1093/ndt/gfn657

41. Izzedine $\mathrm{H}$, Escudier $\mathrm{B}$, Lhomme $\mathrm{C}$, Pautier $\mathrm{P}$, Rouvier $\mathrm{P}$, Gueutin V, Baumelou A, Derosa L, Bahleda R, Hollebecque A, Sahali D, Soria JC (2014) Kidney diseases associated with anti-vascular endothelial growth factor (VEGF): an 8-year observational study at a single center. Medicine (Baltimore) 93(24):333-339. https:// doi.org/10.1097/MD.0000000000000207

42. Launay-Vacher V, Ayllon J, Janus N, Medioni J, Deray G, Isnard-Bagnis C, Oudard S (2011) Evolution of renal function in patients treated with antiangiogenics after nephrectomy for renal cell carcinoma. Urol Oncol 29(5):492-494. https://doi. org/10.1016/j.urolonc.2009.07.023

43. Khan G, Golshayan A, Elson P, Wood L, Garcia J, Bukowski R, Rini B (2010) Sunitinib and sorafenib in metastatic renal cell carcinoma patients with renal insufficiency. Ann Oncol 21(8):1618-1622. https://doi.org/10.1093/annonc/mdp603

44. Khosravan R, Toh M, Garrett M, La Fargue J, Ni G, Marbury TC, Swan SK, Lunde NM, Bello CL (2010) Pharmacokinetics and safety of sunitinib malate in subjects with impaired renal function. J Clin Pharmacol 50(4):472-481. https://doi.org/10. 1177/0091270009347868

45. Smith W, Marbury T, Kipnes M, Cihon F, Lettieri J, Mazzu A (2007) Effects of renal impairment on the pharmacokinetics of sorafenib and its metabolites. Cancer Res 67(9 Supplement):934

46. Chen Y, Rini BI, Motzer RJ, Dutcher JP, Rixe O, Wilding G, Stadler WM, Tarazi J, Garrett M, Pithavala YK (2016) Effect of renal impairment on the pharmacokinetics and safety of axitinib. Target Oncol 11(2):229-234. https://doi.org/10.1007/ s11523-015-0389-2

47. Macfarlane R, Heng DYC, Xie W, Knox JJ, McDermott DF, Rini BI, Kollmannsberger C, Choueiri TK (2012) The impact of kidney function on the outcome of metastatic renal cell carcinoma patients treated with vascular endothelial growth factor-targeted therapy. Cancer 118(2):365-370. https://doi.org/10.1002/cncr. 26201

48. Masini C, Vitale MG, Maruzzo M, Procopio G, de Giorgi U, Buti S, Rossetti S, Iacovelli R, Atzori F, Cosmai L, Vignani F, Prati G, Scagliarini S, Guida A, Berselli A, Pinto C (2019) Safety and efficacy of pazopanib in first-line metastatic renal-cell carcinoma with or without renal failure: CORE-URO-01 study. Clin Genitourin Cancer 17(1):e150-e155. https://doi.org/10.1016/j.clgc. 2018.10.001

49. Kennoki T, Kondo T, Kimata N, Murakami J, Ishimori I, Nakazawa H, Hashimoto Y, Kobayashi H, Iizuka J, Takagi T, Yoshida K, Tanabe K (2011) Clinical results and pharmacokinetics of sorafenib in chronic hemodialysis patients with metastatic renal cell carcinoma in a single center. Jpn J Clin Oncol 41(5):647655. https://doi.org/10.1093/jjco/hyr015
50. Izzedine H, Etienne-Grimaldi MC, Renée N, Vignot S, Milano G (2009) Pharmacokinetics of sunitinib in hemodialysis. Ann Oncol 20(1):190-192. https://doi.org/10.1093/annonc/mdn626

51. Thiery-Vuillemin A, Orillard E, Mouillet G, Calcagno F, Devillard N, Bouchet S, Royer B (2017) Hemodialysis does not impact axitinib exposure: clinical case of a patient with metastatic renal cell carcinoma. Cancer Chemother Pharmacol 79(6):1273-1276. https://doi.org/10.1007/s00280-017-3320-y

52. Noda S, Hira D, Kageyama S, Jo F, Wada A, Yoshida T, Kawauchi A, Morita S-y, Terada T (2016) Pharmacokinetic analysis of a hemodialyzed patient treated with pazopanib. Clin Genitourin Cancer 14(4):e453-e456. https://doi.org/10.1016/j. clgc.2016.03.016

53. Leonetti A, Bersanelli M, Castagneto B, Masini C, Di Meglio G, Pellegrino B, Buti S (2016) Outcome and safety of sorafenib in metastatic renal cell carcinoma dialysis patients: a systematic review. Clin Genitourin Cancer 14(4):277-283. https://doi.org/ 10.1016/j.clgc.2016.01.010

54. Gore ME, Szczylik C, Porta C, Bracarda S, Bjarnason GA, Oudard S, Hariharan S, Lee SH, Haanen J, Castellano D, Vrdoljak E, Schöffski P, Mainwaring P, Nieto A, Yuan J, Bukowski R (2009) Safety and efficacy of sunitinib for metastatic renal-cell carcinoma: an expanded-access trial. Lancet Oncol 10(8):757-763. https://doi.org/10.1016/s1470-2045(09)70162-7

55. Stadler WM, Figlin RA, McDermott DF, Dutcher JP, Knox JJ, Miller WH Jr, Hainsworth JD, Henderson CA, George JR, Hajdenberg J, Kindwall-Keller TL, Ernstoff MS, Drabkin HA, Curti BD, Chu L, Ryan CW, Hotte SJ, Xia C, Cupit L, Bukowski RM (2010) Safety and efficacy results of the advanced renal cell carcinoma sorafenib expanded access program in North America. Cancer 116(5):1272-1280. https://doi.org/10.1002/cncr.24864

56. Bersanelli M, Facchinetti F, Tiseo M, Maiorana M, Buti S (2016) Pazopanib in renal cell carcinoma dialysis patients: a mini-review and a case report. Curr Drug Targets 17(15):1755-1760. https:// doi.org/10.2174/1389450117666160112114756

57. Ishihara H, Takagi $\mathrm{T}$, Kondo $\mathrm{T}$, Yoshida K, Okumi M, Tanabe K (2019) Efficacy and safety of axitinib for metastatic renal cell carcinoma in patients on hemodialysis for end-stage renal disease: case series of eight patients. Int J Urol 26(11):1081-1082. https://doi.org/10.1111/iju.14093

58. Pham A, Ye D-W, Pal S (2015) Overview and management of toxicities associated with systemic therapies for advanced renal cell carcinoma. Urol Oncol Semin Orig Investig 33(12):517-527. https://doi.org/10.1016/j.urolonc.2015.07.020

59. Paluri RK, Sonpavde G, Morgan C, Rojymon J, Mar AH, Gangaraju R (2019) Renal toxicity with mammalian target of rapamycin inhibitors: a meta-analysis of randomized clinical trials. Oncol Rev 13(2):455-455. https://doi.org/10.4081/oncol.2019.455

60. Choueiri TK, Je Y, Sonpavde G, Richards CJ, Galsky MD, Nguyen PL, Schutz F, Heng DY, Kaymakcalan MD (2013) Incidence and risk of treatment-related mortality in cancer patients treated with the mammalian target of rapamycin inhibitors. Ann Oncol 24(8):2092-2097. https://doi.org/10.1093/annonc/mdt155

61. Bertoni E, Bruschi M, Candiano G, Boccardi C, Citti L, Mangraviti S, Rosso G, Larti A, Rosati A, Ghiggeri GM, Salvadori M (2009) Posttransplant proteinuria associated with everolimus. Transpl Proc 41(4):1216-1217. https://doi.org/10.1016/j.trans proceed.2009.03.093

62. Lieberthal W, Fuhro R, Andry CC, Rennke H, Abernathy VE, Koh JS, Valeri R, Levine JS (2001) Rapamycin impairs recovery from acute renal failure: role of cell-cycle arrest and apoptosis of tubular cells. Am J Physiol Renal Physiol 281(4):F693-706. https://doi.org/10.1152/ajprenal.2001.281.4.F693

63. Lieberthal W, Fuhro R, Andry C, Patel V, Levine JS (2006) Rapamycin delays but does not prevent recovery from acute renal failure: role of acquired tubular resistance. Transplantation 
82(1):17-22. https://doi.org/10.1097/01.tp.0000225772.22757. $5 \mathrm{e}$

64. Nakagawa S, Nishihara K, Inui K-i, Masuda S (2012) Involvement of autophagy in the pharmacological effects of the mTOR inhibitor everolimus in acute kidney injury. Eur J Pharmacol 696(1):143-154. https://doi.org/10.1016/j.ejphar.2012.09.010

65. Izzedine H, Escudier B, Rouvier P, Gueutin V, Varga A, Bahleda R, Soria JC (2013) Acute tubular necrosis associated with mTOR inhibitor therapy: a real entity biopsy-proven. Ann Oncol 24(9):2421-2425. https://doi.org/10.1093/annonc/mdt233

66. Vogelbacher R, Wittmann S, Braun A, Daniel C, Hugo C (2007) The mTOR inhibitor everolimus induces proteinuria and renal deterioration in the remnant kidney model in the rat. Transplantation 84(11):1492-1499. https://doi.org/10.1097/01.tp.00002 82866.92367.99

67. Sarbassov DD, Ali SM, Sengupta S, Sheen J-H, Hsu PP, Bagley AF, Markhard AL, Sabatini DM (2006) Prolonged rapamycin treatment inhibits mTORC2 assembly and Akt/PKB. Mol Cell 22(2):159-168. https://doi.org/10.1016/j.molcel.2006.03.029

68. Letavernier E, Legendre C (2008) mToR inhibitors-induced proteinuria: mechanisms, significance, and management. Transplant Rev 22(2):125-130. https://doi.org/10.1016/j.trre.2007.12.001

69. Ha SH, Park JH, Jang HR, Huh W, Lim H-Y, Kim Y-G, Kim DJ, Oh HY, Lee JE (2014) Increased risk of everolimus-associated acute kidney injury in cancer patients with impaired kidney function. BMC Cancer 14:906-906. https://doi.org/10.1186/ 1471-2407-14-906

70. Kim KH, Kim JH, Lee JY, Kim HS, Heo SJ, Kim JH, Kim HY, Rha SY (2016) Efficacy and toxicity of mammalian target rapamycin inhibitors in patients with metastatic renal cell carcinoma with renal insufficiency: the Korean Cancer Study Group GU 14-08. Cancer Res Treat 48(4):1286-1292. https://doi.org/10. 4143/crt.2016.018

71. Lunardi G, Vannozzi MO, Armirotti A, Nicodemo M, Venturini M, Cavallini L (2008) Temsirolimus in patients with renal cancer on hemodialysis. J Clin Oncol 26 (34):5652-5653; author reply 5653-5654. https://doi.org/10.1200/JCO.2008.19.3144

72. Thiery-Vuillemin A, Curtit E, Maurina T, Montange D, Succi C, Nguyen T, Kim S, Montcuquet P, Pivot X, Royer B (2012) Hemodialysis does not affect everolimus pharmacokinetics: two cases of patients with metastatic renal cell cancer. Ann Oncol 23(11):2992-2993. https://doi.org/10.1093/annonc/mds477

73. Guida A, Masini C, Milella M, Di Lorenzo G, Santoni M, Prati V, Porta C, Cosmai L, Donati D, del Giovane C, Mighali P, Sabbatini R (2015) Retrospective analysis on safety and efficacy of everolimus in treatment of metastatic renal cancer patients receiving dialysis. Future Oncol 11(23):3159-3166. https://doi. org/10.2217/fon.15.256

74. Motzer RJ, Escudier B, Oudard S, Hutson TE, Porta C, Bracarda S, Grünwald V, Thompson JA, Figlin RA, Hollaender N, Kay A, for the R-SG (2010) Phase 3 trial of everolimus for metastatic renal cell carcinoma. Cancer 116(18):4256-4265. https://doi.org/ 10.1002/cncr.25219

75. Escudier B, Porta C, Schmidinger M, Rioux-Leclercq N, Bex A, Khoo V, Grünwald V, Gillessen S, Horwich A (2019) Renal cell carcinoma: ESMO clinical practice guidelines for diagnosis, treatment and follow-up $\dagger$. Ann Oncol 30(5):706-720. https://doi. org/10.1093/annonc/mdz056

76. Longo DLMD, Postow MAMD, Sidlow RMD, Hellmann MDMD (2018) Immune-related adverse events associated with immune checkpoint blockade. N Engl J Med 378(2):158-168. https://doi.org/10.1056/NEJMra1703481

77. Seethapathy H, Zhao S, Chute DF, Zubiri L, Oppong Y, Strohbehn I, Cortazar FB, Leaf DE, Mooradian MJ, Villani A-C, Sullivan RJ, Reynolds K, Sise ME (2019) The incidence, causes, and risk factors of acute kidney injury in patients receiving immune checkpoint inhibitors. Clin J Am Soc Nephrol 14(12):1692. https://doi.org/10.2215/CJN.00990119

78. Manohar S, Kompotiatis P, Thongprayoon C, Cheungpasitporn W, Herrmann J, Herrmann SM (2018) Programmed cell death protein 1 inhibitor treatment is associated with acute kidney injury and hypocalcemia: meta-analysis. Nephrol Dial Transplant 34(1):108-117. https://doi.org/10.1093/ndt/gfy105

79. Motzer RJ, Rini BI, McDermott DF, Arén Frontera O, Hammers HJ, Carducci MA, Salman P, Escudier B, Beuselinck B, Amin A, Porta C, George S, Neiman V, Bracarda S, Tykodi SS, Barthélémy P, Leibowitz-Amit R, Plimack ER, Oosting SF, Redman B, Melichar B, Powles T, Nathan P, Oudard S, Pook D, Choueiri TK, Donskov F, Grimm M-O, Gurney H, Heng DYC, Kollmannsberger CK, Harrison MR, Tomita Y, Duran I, Grünwald V, McHenry MB, Mekan S, Tannir NM (2019) Nivolumab plus ipilimumab versus sunitinib in first-line treatment for advanced renal cell carcinoma: extended follow-up of efficacy and safety results from a randomised, controlled, phase 3 trial. Lancet Oncol 20(10):1370-1385. https://doi.org/10.1016/S1470-2045(19) 30413-9

80. Cortazar FB, Marrone KA, Troxell ML, Ralto KM, Hoenig MP, Brahmer JR, Le DT, Lipson EJ, Glezerman IG, Wolchok J, Cornell LD, Feldman P, Stokes MB, Zapata SA, Hodi FS, Ott PA, Yamashita M, Leaf DE (2016) Clinicopathological features of acute kidney injury associated with immune checkpoint inhibitors. Kidney Int 90(3):638-647. https://doi.org/10.1016/j.kint. 2016.04.008

81. Motzer RJ, Penkov K, Haanen J, Rini B, Albiges L, Campbell MT, Venugopal B, Kollmannsberger C, Negrier S, Uemura M, Lee JL, Vasiliev A, Miller WH, Gurney H, Schmidinger M, Larkin J, Atkins MB, Bedke J, Alekseev B, Wang J, Mariani M, Robbins PB, Chudnovsky A, Fowst C, Hariharan S, Huang B, di Pietro A, Choueiri TK (2019) Avelumab plus axitinib versus sunitinib for advanced renal-cell carcinoma. N Engl J Med 380(12):1103-1115. https://doi.org/10.1056/NEJMoa1816047

82. Powles T, Plimack ER, Soulières D, Waddell T, Stus V, Gafanov R, Nosov D, Pouliot F, Melichar B, Vynnychenko I, Azevedo SJ, Borchiellini D, McDermott RS, Bedke J, Tamada S, Yin L, Chen M, Molife LR, Atkins MB, Rini BI (2020) Pembrolizumab plus axitinib versus sunitinib monotherapy as first-line treatment of advanced renal cell carcinoma (KEYNOTE-426): extended follow-up from a randomised, open-label, phase 3 trial. Lancet Oncol 21(12):1563-1573. https://doi.org/10.1016/S14702045(20)30436-8

83. Amin A, Plimack ER, Ernstoff MS, Lewis LD, Bauer TM, McDermott DF, Carducci M, Kollmannsberger C, Rini BI, Heng DYC, Knox J, Voss MH, Spratlin J, Berghorn E, Yang L, Hammers HJ (2018) Safety and efficacy of nivolumab in combination with sunitinib or pazopanib in advanced or metastatic renal cell carcinoma: the CheckMate 016 study. J Immunother Cancer 6(1):109. https://doi.org/10.1186/s40425-018-0420-0

84. Lo WK, Yau T, Chang TYA, Chan KW (2020) SAT-024 Glomerulonephritis induced by combination immunotherapy and VEGF inhibition with tyrosine kinase inhibitors (TKI). Kidney Int Rep 5(3):S12. https://doi.org/10.1016/j.ekir.2020.02.028

85. Perazella MA, Shirali AC (2020) Immune checkpoint inhibitor nephrotoxicity: what do we know and what should we do? Kidney Int 97(1):62-74. https://doi.org/10.1016/j.kint.2019.07.022

86. Cortazar FB, Kibbelaar ZA, Glezerman IG, Abudayyeh A, Mamlouk O, Motwani SS, Murakami N, Herrmann SM, Manohar S, Shirali AC, Kitchlu A, Shirazian S, Assal A, Vijayan A, Renaghan AD, Ortiz-Melo DI, Rangarajan S, Malik AB, Hogan JJ, Dinh AR, Shin DS, Marrone KA, Mithani Z, Johnson DB, Hosseini A, Uprety D, Sharma S, Gupta S, Reynolds KL, Sise ME, Leaf DE (2020) Clinical features and outcomes of immune checkpoint inhibitor-associated AKI: a multicenter study. J Am 
Soc Nephrol 31(2):435-446. https://doi.org/10.1681/asn.20190 70676

87. Mamlouk O, Selamet U, Machado S, Abdelrahim M, Glass WF, Tchakarov A, Gaber L, Lahoti A, Workeneh B, Chen S, Lin J, Abdel-Wahab N, Tayar J, Lu H, Suarez-Almazor M, Tannir N, Yee C, Diab A, Abudayyeh A (2019) Nephrotoxicity of immune checkpoint inhibitors beyond tubulointerstitial nephritis: singlecenter experience. J Immunother Cancer 7(1):2-2. https://doi. org/10.1186/s40425-018-0478-8

88. Shingarev R, Glezerman IG (2019) Kidney complications of immune checkpoint inhibitors: a review. Am J Kidney Dis 74(4):529-537. https://doi.org/10.1053/j.ajkd.2019.03.433

89. Gupta S, Cortazar FB, Riella LV, Leaf DE (2020) Immune checkpoint inhibitor nephrotoxicity: update 2020. Kidney 360 1(2):130-140. https://doi.org/10.34067/kid.0000852019

90. Wanchoo R, Karam S, Uppal NN, Barta VS, Deray G, Devoe C, Launay-Vacher V, Jhaveri KD (2017) Adverse renal effects of immune checkpoint inhibitors: a narrative review. Am J Nephrol 45(2):160-169. https://doi.org/10.1159/000455014

91. Granier C, De Guillebon E, Blanc C, Roussel H, Badoual C, Colin E, Saldmann A, Gey A, Oudard S, Tartour E (2017) Mechanisms of action and rationale for the use of checkpoint inhibitors in cancer. ESMO Open 2(2):e000213. https://doi.org/10.1136/ esmoopen-2017-000213

92. Tivol EA, Borriello F, Schweitzer AN, Lynch WP, Bluestone JA, Sharpe AH (1995) Loss of CTLA-4 leads to massive lymphoproliferation and fatal multiorgan tissue destruction, revealing a critical negative regulatory role of CTLA-4. Immunity 3(5):541-547. https://doi.org/10.1016/1074-7613(95)90125-6

93. Nishimura H, Nose M, Hiai H, Minato N, Honjo T (1999) Development of lupus-like autoimmune diseases by disruption of the PD-1 gene encoding an ITIM motif-carrying immunoreceptor. Immunity 11(2):141-151. https://doi.org/10.1016/ s1074-7613(00)80089-8

94. Herrmann SM, Perazella MA (2020) Immune checkpoint inhibitors and immune-related adverse renal events. Kidney Int Rep 5(8):1139-1148. https://doi.org/10.1016/j.ekir.2020.04.018

95. Perazella MA, Sprangers B (2019) AKI in patients receiving immune checkpoint inhibitors. Clin J Am Soc Nephrol 14(7):1077-1079. https://doi.org/10.2215/CJN.02340219

96. Brahmer JR, Lacchetti C, Schneider BJ, Atkins MB, Brassil KJ, Caterino JM, Chau I, Ernstoff MS, Gardner JM, Ginex P, Hallmeyer S, Holter Chakrabarty J, Leighl NB, Mammen JS, McDermott DF, Naing A, Nastoupil LJ, Phillips T, Porter LD, Puzanov I, Reichner CA, Santomasso BD, Seigel C, Spira A, Suarez-Almazor ME, Wang Y, Weber JS, Wolchok JD, Thompson JA (2018) Management of immune-related adverse events in patients treated with immune checkpoint inhibitor therapy: american society of clinical oncology clinical practice guideline. J Clin Oncol 36(17):1714-1768. https://doi.org/10.1200/ jco.2017.77.6385

97. Haanen JBAG, Carbonnel F, Robert C, Kerr KM, Peters S, Larkin J, Jordan K (2017) Management of toxicities from immunotherapy: ESMO clinical practice guidelines for diagnosis, treatment and follow-up. Ann Oncol 28:119-142. https://doi. org/10.1093/annonc/mdx225

98. Koda R, Watanabe H, Tsuchida M, Iino N, Suzuki K, Hasegawa G, Imai N, Narita I (2018) Immune checkpoint inhibitor (nivolumab)-associated kidney injury and the importance of recognizing concomitant medications known to cause acute tubulointerstitial nephritis: a case report. BMC Nephrol 19(1):48. https://doi.org/10.1186/s12882-018-0848-y

99. Bajaj G, Wang X, Agrawal S, Gupta M, Roy A, Feng Y (2017) Model-based population pharmacokinetic analysis of nivolumab in patients with solid tumors. CPT Pharmacomet
Syst Pharmacol 6(1):58-66. https://doi.org/10.1002/psp4. 12143

100. Balar AV, Galsky MD, Rosenberg JE, Powles T, Petrylak DP, Bellmunt J, Loriot Y, Necchi A, Hoffman-Censits J, Perez-Gracia JL, Dawson NA, van der Heijden MS, Dreicer R, Srinivas S, Retz MM, Joseph RW, Drakaki A, Vaishampayan UN, Sridhar SS, Quinn DI, Durán I, Shaffer DR, Eigl BJ, Grivas PD, Yu EY, Li S, Kadel EE, Boyd Z, Bourgon R, Hegde PS, Mariathasan S, Thåström A, Abidoye OO, Fine GD, Bajorin DF (2017) Atezolizumab as first-line treatment in cisplatin-ineligible patients with locally advanced and metastatic urothelial carcinoma: a singlearm, multicentre, phase 2 trial. Lancet 389(10064):67-76. https:// doi.org/10.1016/S0140-6736(16)32455-2

101. Tachibana H, Kondo T, Ishihara H, Takagi T, Tanabe K (2019) Safety and efficacy of nivolumab in patients with metastatic renal cell carcinoma and end-stage renal disease at 2 centers. Clin Genitourin Cancer 17(4):e772-e778. https://doi.org/10.1016/j. clgc.2019.04.004

102. Capasso A, Benigni A, Capitanio U, Danesh FR, Di Marzo V, Gesualdo L, Grandaliano G, Jaimes EA, Malyszko J, Perazella MA, Qian Q, Ronco P, Rosner MH, Trepiccione F, Viggiano D, Zoccali C, Capasso G, International Conference on OncoNephrology P (2019) Summary of the International Conference on Onco-Nephrology: an emerging field in medicine. Kidney Int 96(3):555-567. https://doi.org/10.1016/j.kint.2019.04.043

103. Malyszko J, Tesarova P, Capasso G, Capasso A (2020) The link between kidney disease and cancer: complications and treatment. Lancet 396(10246):277-287. https://doi.org/10.1016/S01406736(20)30540-7

104. Motzer RJ, Hutson TE, Olsen MR, Hudes GR, Burke JM, Edenfield WJ, Wilding G, Agarwal N, Thompson JA, Cella D, Bello A, Korytowsky B, Yuan J, Valota O, Martell B, Hariharan S, Figlin RA (2012) Randomized phase II trial of sunitinib on an intermittent versus continuous dosing schedule as first-line therapy for advanced renal cell carcinoma. J Clin Oncol 30(12):1371-1377. https://doi.org/10.1200/JCO.2011.36.4133

105. Motzer RJ, Rini BI, Bukowski RM, Curti BD, George DJ, Hudes GR, Redman BG, Margolin KA, Merchan JR, Wilding G, Ginsberg MS, Bacik J, Kim ST, Baum CM, Michaelson MD (2006) Sunitinib in patients with metastatic renal cell carcinoma. JAMA J Am Med Assoc 295(21):2516-2524. https://doi.org/10.1001/ jama.295.21.2516

106. Motzer RJ, Barrios CH, Kim TM, Falcon S, Cosgriff T, Harker WG, Pittman KB, Sabbatini R, Rha SY, Flaig TW, Page RD, Bavbek SE, Beck JT, Patel PM, Schiff E, Vaury A, Niolat J, Gogov S, Anak O, Knox J (2013) Record-3: Phase II randomized trial comparing sequential first-line everolimus (EVE) and second-line sunitinib (SUN) versus first-line SUN and second-line EVE in patients with metastatic renal cell carcinoma (mRCC). J Clin Oncol 31(suppl):abstr 4504

107. Hutson TE, Davis ID, Machiels JP, De Souza PL, Rottey S, Hong BF, Epstein RJ, Baker KL, McCann L, Crofts T, Pandite L, Figlin RA (2010) Efficacy and safety of pazopanib in patients with metastatic renal cell carcinoma. J Clin Oncol 28(3):475-480. https://doi.org/10.1200/JCO.2008.21.6994

108. Hainsworth JD, Rubin MS, Arrowsmith ER, Khatcheressian J, Crane EJ, Franco LA (2013) Pazopanib as second-line treatment after sunitinib or bevacizumab in patients with advanced renal cell carcinoma: a Sarah Cannon Oncology Research Consortium Phase II Trial. Clin Genitourin Cancer 11(3):270-275. https:// doi.org/10.1016/j.clgc.2013.04.006

109. Sternberg CN, Davis ID, Mardiak J, Szczylik C, Lee E, Wagstaff J, Barrios CH, Salman P, Gladkov OA, Kavina A, Zarba JJ, Chen M, McCann L, Pandite L, Roychowdhury DF, Hawkins RE (2010) Pazopanib in locally advanced or metastatic renal cell 
carcinoma: results of a randomized phase III trial. J Clin Oncol 28(6):1061-1068. https://doi.org/10.1200/JCO.2009.23.9764

110. Sternberg CN, Hawkins RE, Wagstaff J, Salman P, Mardiak J, Barrios CH, Zarba JJ, Gladkov OA, Lee E, Szczylik C, McCann L, Rubin SD, Chen M, Davis ID (2013) A randomised, doubleblind phase III study of pazopanib in patients with advanced and/ or metastatic renal cell carcinoma: final overall survival results and safety update. Eur J Cancer 49(6):1287-1296. https://doi. org/10.1016/j.ejca.2012.12.010

111. Escudier B, Eisen T, Stadler WM, Szczylik C, Oudard S, Siebels M, Negrier S, Chevreau C, Solska E, Desai AA, Rolland F, Demkow T, Hutson TE, Gore M, Freeman S, Schwartz B, Shan M, Simantov R, Bukowski RM, Group TS (2007) Sorafenib in advanced clear-cell renal-cell carcinoma. N Engl J Med 356(2):125-134. https://doi.org/10.1056/NEJMoa060655

112. Escudier B, Eisen T, Stadler WM, Szczylik C, Oudard S, Staehler M, Negrier S, Chevreau C, Desai AA, Rolland F, Demkow T, Hutson TE, Gore M, Anderson S, Hofilena G, Shan M, Pena C, Lathia C, Bukowski RM (2009) Sorafenib for treatment of renal cell carcinoma: Final efficacy and safety results of the phase III treatment approaches in renal cancer global evaluation trial. J Clin Oncol 27(20):3312-3318. https://doi.org/10.1200/JCO. 2008.19.5511

113. Hutson TE, Escudier B, Esteban E, Bjarnason GA, Lim HY, Pittman KB, Senico P, Niethammer A, Lu DR, Hariharan S, Motzer RJ (2014) Randomized phase III trial of temsirolimus versus sorafenib as second-line therapy after sunitinib in patients with metastatic renal cell carcinoma. J Clin Oncol 32(8):760-767. https://doi.org/10.1200/JCO.2013.50.3961

114. Rixe O, Bukowski RM, Michaelson MD, Wilding G, Hudes GR, Bolte O, Motzer RJ, Bycott P, Liau KF, Freddo J, Trask PC, Kim S, Rini BI (2007) Axitinib treatment in patients with cytokinerefractory metastatic renal-cell cancer: a phase II study. Lancet Oncol 8(11):975-984. https://doi.org/10.1016/S1470-2045(07) 70285-1

115. Eto M, Uemura H, Tomita Y, Kanayama H, Shinohara N, Kamei Y, Fujii Y, Umeyama Y, Ozono S, Naito S, Akaza H, Japan Axitinib Phase IISG (2014) Overall survival and final efficacy and safety results from a Japanese phase II study of axitinib in cytokine-refractory metastatic renal cell carcinoma. Cancer Sci 105(12):1576-1583. https://doi.org/10.1111/cas.12546

116. Motzer RJ, Escudier B, Tomczak P, Hutson TE, Michaelson MD, Negrier S, Oudard S, Gore ME, Tarazi J, Hariharan S, Chen C, Rosbrook B, Kim S, Rini BI (2013) Axitinib versus sorafenib as second-line treatment for advanced renal cell carcinoma: overall survival analysis and updated results from a randomised phase 3 trial. Lancet Oncol 14(6):552-562. https://doi.org/10.1016/ S1470-2045(13)70093-7

117. Qin S, Bi F, Jin J, Cheng Y, Guo J, Ren X, Huang Y, Tarazi J, Tang J, Chen C, Kim S, Ye D (2015) Axitinib versus sorafenib as a second-line therapy in Asian patients with metastatic renal cell carcinoma: results from a randomized registrational study. Onco Targets Ther 8:1363-1373. https://doi.org/10.2147/OTT. S83302

118. Hutson TE, Al-Shukri S, Stus VP, Lipatov ON, Shparyk Y, Bair AH, Rosbrook B, Andrews GI, Vogelzang NJ (2017) axitinib versus sorafenib in first-line metastatic renal cell carcinoma: overall survival from a randomized phase III trial. Clin Genitourin Cancer 15(1):72-76. https://doi.org/10.1016/j.clgc.2016.05.008

119. Hutson TE, Lesovoy V, Al-Shukri S, Stus VP, Lipatov ON, Bair AH, Rosbrook B, Chen C, Kim S, Vogelzang NJ (2013) Axitinib versus sorafenib as first-line therapy in patients with metastatic renal-cell carcinoma: a randomised open-label phase 3 trial. Lancet Oncol 14(13):1287-1294. https://doi.org/10.1016/ S1470-2045(13)70465-0
120. George DJ, Hessel C, Halabi S, Michaelson MD, Hahn O, Walsh M, Picus J, Small EJ, Dakhil S, Feldman DR, Mangeshkar M, Scheffold C, Morris MJ, Choueiri TK (2019) Cabozantinib versus sunitinib for untreated patients with advanced renal cell carcinoma of intermediate or poor risk: subgroup analysis of the alliance A031203 CABOSUN trial. Oncologist 24(11):1497-1501. https://doi.org/10.1634/theoncologist.2019-0316

121. Choueiri TK, Halabi S, Sanford BL, Hahn O, Michaelson MD, Walsh MK, Feldman DR, Olencki T, Picus J, Small EJ, Dakhil S, George DJ, Morris MJ (2017) Cabozantinib versus sunitinib as initial targeted therapy for patients with metastatic renal cell carcinoma of poor or intermediate risk: the alliance A031203 CABOSUN trial. J Clin Oncol 35(6):591-597. https://doi.org/ 10.1200/JCO.2016.70.7398

122. Choueiri TK, Hessel C, Halabi S, Sanford B, Michaelson MD, Hahn O, Walsh M, Olencki T, Picus J, Small EJ, Dakhil S, Feldman DR, Mangeshkar M, Scheffold C, George D, Morris MJ (2018) Cabozantinib versus sunitinib as initial therapy for metastatic renal cell carcinoma of intermediate or poor risk (alliance A031203 CABOSUN randomised trial): progression-free survival by independent review and overall survival update. Eur J Cancer 94:115-125. https://doi.org/10.1016/j.ejca.2018.02.012

123. Choueiri TK, Escudier B, Powles T, Tannir NM, Mainwaring PN, Rini BI, Hammers HJ, Donskov F, Roth BJ, Peltola K, Lee JL, Heng DYC, Schmidinger M, Agarwal N, Sternberg CN, McDermott DF, Aftab DT, Hessel C, Scheffold C, Schwab G, Hutson TE, Pal S, Motzer RJ, Investigators M (2016) Cabozantinib versus everolimus in advanced renal cell carcinoma (METEOR): final results from a randomised, open-label, phase 3 trial. Lancet Oncol 17(7):917-927. https://doi.org/10.1016/S1470-2045(16) 30107-3

124. Choueiri TK, Escudier B, Powles T, Mainwaring PN, Rini BI, Donskov F, Hammers H, Hutson TE, Lee JL, Peltola K, Roth BJ, Bjarnason GA, Geczi L, Keam B, Maroto P, Heng DY, Schmidinger M, Kantoff PW, Borgman-Hagey A, Hessel C, Scheffold C, Schwab GM, Tannir NM, Motzer RJ, Investigators M (2015) Cabozantinib versus everolimus in advanced renal-cell carcinoma. N Engl J Med 373(19):1814-1823. https://doi.org/10. 1056/NEJMoa1510016

125. Pfizer Inc.. Sutent (sunitinib) [package insert]. U.S. Food and Drug Administration website. https://www.accessdata.fda.gov/ drugsatfda_docs/label/2020/021938s037lbl.pdf. Revised Aug 2020. Accessed 20 Oct 2020

126. Bayer HealthCare Pharmaceuticals Inc.. Nexavar (sorafenib) [package insert]. U.S. Food and Drug Administration website. https://www.accessdata.fda.gov/drugsatfda_docs/label/2020/ 021923s024lblrpl.pdf. Revised June 2020. Accessed 2020 Oct 2020

127. Novartis Pharmaceuticals Corporation. Votrient (pazopanib) [package insert]. U.S. Food and Drug Administration website. https://www.accessdata.fda.gov/drugsatfda_docs/label/2020/ 022465s029lbl.pdf. Revised Aug 2020. Accessed 20 Oct 2020

128. Pfizer Inc.. Inlyta (axitinib) [package insert]. U.S. Food and Drug Administration website. https://www.accessdata.fda.gov/drugs atfda_docs/label/2020/202324s011lbl.pdf. Revised June 2020. Accessed 20 Oct 2020

129. Novartis Pharmaceuticals Corporation. Afinitor (everolimus) [package insert]. U.S. Food and Drug Administration website. https://www.accessdata.fda.gov/drugsatfda_docs/label/2020/ 022334s044,203985s0161bl.pdf. Revised Feb 2020. Accessed 20 Oct 2020

130. Wyeth Pharmaceuticals Inc.. Torisel (temsirolimus) [package insert]. U.S. Food and Drug Administration website. https:// www.accessdata.fda.gov/drugsatfda_docs/label/2018/02208 8s021s023lbl.pdf. Revised Mar 2018. Accessed 20 Oct 2020 
131. Bristol-Myers Squibb Company. Yervoy (ipilimumab) [package insert]. U.S. Food and Drug Administration website. https:// www.accessdata.fda.gov/drugsatfda_docs/label/2020/12537 7s115lbl.pdf. Revised Oct 2020. Accessed 20 Oct 2020

132. Bristol-Myers Squibb Company. Opdivo (nivolumab) [package insert]. U.S. Food and Drug Administration website. https:// www.accessdata.fda.gov/drugsatfda_docs/label/2020/12555 4s089lbl.pdf. Revised Oct 2020. Accessed 20 Oct 2020

133. Merck Sharp \& Dohme Corp.. Keytruda (pembrolizumab) [package insert]. U.S. Food and Drug Administration website. https:// www.accessdata.fda.gov/drugsatfda_docs/label/2020/12551 4s085lbl.pdf. Revised Oct 2020. Accessed 20 Oct 2020

134. Genentech Inc.. Tecentriq (atezolizumab) [package insert]. U.S. Food and Drug Administration website. https://www.accessdata. fda.gov/drugsatfda_docs/label/2020/761034s029lbl.pdf. Revised Sept 2020. Accessed 20 Oct 2020

135. Josephs D, Hutson TE, Cowey CL, Pickering LM, Larkin JM, Gore ME, Van Hemelrijck M, McDermott DF, Powles T, Chowdhury P, Karapetis C, Harper PG, Choueiri TK, Chowdhury S (2011) Efficacy and toxicity of sunitinib in patients with metastatic renal cell carcinoma with severe renal impairment or on haemodialysis. BJU Int 108(8):1279-1283. https://doi.org/10. 1111/j.1464-410X.2010.09990.x

136. Casper J, Goebel D, Gruenwald V, Flörcken A, Mueller D, Toussaint K, Metzner B (2011) Efficacy and safety of sunitinib in patients with metastatic renal cell carcinoma on hemodialysis. J Clin Oncol 29(15_suppl):4646-4646. https://doi.org/10.1200/ jco.2011.29.15_suppl.4646

137. Masini C, Sabbatini R, Porta C, Procopio G, Di Lorenzo G, Onofri A, Buti S, Iacovelli R, Invernizzi R, Moscetti L, Aste MG, Pagano M, Grosso F, Lucia Manenti A, Ortega C, Cosmai L, Del Giovane C, Conte PF (2012) Use of tyrosine kinase inhibitors in patients with metastatic kidney cancer receiving haemodialysis: a retrospective Italian survey. BJU Int 110(5):692-698. https:// doi.org/10.1111/j.1464-410X.2012.10946.x

138. Shetty AV, Matrana MR, Atkinson BJ, Flaherty AL, Jonasch E, Tannir NM (2014) Outcomes of patients with metastatic renal cell carcinoma and end-stage renal disease receiving dialysis and targeted therapies: a single institution experience. Clin Genitourin Cancer 12(5):348-353. https://doi.org/10.1016/j.clgc.2014. 01.004

139. Czarnecka AM, Kawecki M, Lian F, Korniluk J, Szczylik C (2015) Feasibility, efficacy and safety of tyrosine kinase inhibitor treatment in hemodialyzed patients with renal cell cancer: 10 years of experience. Future Oncol 11(16):2267-2282. https://doi. org/10.2217/fon. 15.112

140. Omae K, Kondo T, Kennoki T, Takagi T, Iizuka J, Kobayashi H, Hashimoto Y, Tanabe K (2016) Efficacy and safety of sorafenib for treatment of Japanese metastatic renal cell carcinoma patients undergoing hemodialysis. Int J Clin Oncol 21(1):126-132. https://doi.org/10.1007/s10147-015-0871-y

141. Syrios J, Kechagias G, Tsavaris N (2013) Treatment of patients with metastatic renal cell carcinoma undergoing hemodialysis: case report of two patients and short literature review. BMC Nephrol 14(1):84. https://doi.org/10.1186/1471-2369-14-84

142. Miyake H, Harada K, Kusuda Y, Fujisawa M (2013) Efficacy and safety of temsirolimus in Japanese patients with metastatic renal cell carcinoma on hemodialysis. Int J Clin Oncol 18(6):10541059. https://doi.org/10.1007/s10147-012-0492-7

143. Omae K, Kondo T, Takagi T, Iizuka J, Kobayashi H, Hashimoto Y, Tanabe K (2016) Use of mammalian target of rapamycin inhibitors after failure of tyrosine kinase inhibitors in patients with metastatic renal cell carcinoma undergoing hemodialysis: a single-center experience with four cases. Hemodial Int 20(3):E15. https://doi.org/10.1111/hdi.12390

144. Carlo MI, Feldman DR (2016) Response to nivolumab in a patient with metastatic clear cell renal cell carcinoma and endstage renal disease on dialysis. Eur Urol 70(6):1082-1083. https://doi.org/10.1016/j.eururo.2016.05.040

145. Tabei T, Natsume I, Kobayashi K (2017) Successful treatment of metastatic clear cell carcinoma with nivolumab in a patient receiving dialysis treatment. Int J Urol 24(9):708-710. https:// doi.org/10.1111/iju.13420

146. Ansari J, Ali M, Farrag A, Ali AM, Alhamad A (2018) Efficacy of nivolumab in a patient with metastatic renal cell carcinoma and end-stage renal disease on dialysis: case report and literature review. Case Rep Immunol 2018:1623957-1623957. https://doi. org/10.1155/2018/1623957

147. Cheun H, Kim M, Lee H, Oh KH, Keam B (2019) Safety and efficacy of immune checkpoint inhibitors for end-stage renal disease patients undergoing dialysis: a retrospective case series and literature review. Investig New Drugs 37(3):579-583. https://doi. org/10.1007/s10637-018-0673-y

148. Vitale MG, Baldessari C, Milella M, Buti S, Militello AM, Di Girolamo S, Fornarini G, Perri G, Basso U, Maruzzo M, Porta C, Cosmai L, Pipitone S, Cerma K, Cascinu S, Sabbatini R (2019) Immunotherapy in dialysis-dependent cancer patients: our experience in patients with metastatic renal cell carcinoma and a review of the literature. Clin Genitourin Cancer 17(5):e903e908. https://doi.org/10.1016/j.clgc.2019.06.009

Publisher's Note Springer Nature remains neutral with regard to jurisdictional claims in published maps and institutional affiliations. 